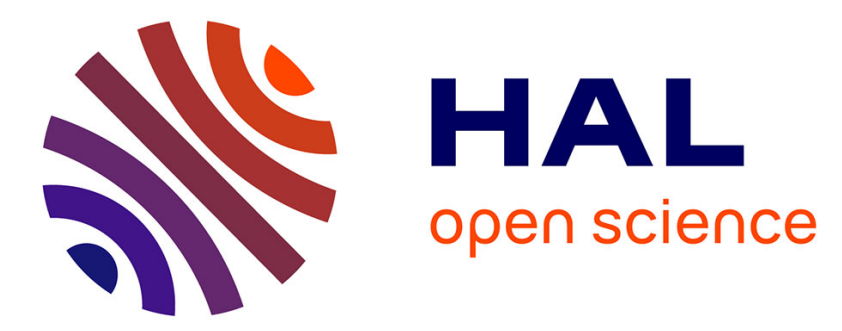

\title{
"Compiling the Actuarial Balance for Pay-As-You-Go Pension Systems. Is it better to use the Hidden Asset or the Contribution Asset?"
}

Carlos Vidal-Melia, Maria Carmen Boado-Penas

\section{- To cite this version: \\ Carlos Vidal-Melia, Maria Carmen Boado-Penas. "Compiling the Actuarial Balance for Pay-As-You- Go Pension Systems. Is it better to use the Hidden Asset or the Contribution Asset?". Applied Economics, 2011, 45 (10), pp.1303-1320. 10.1080/00036846.2011.615733 . hal-00762894}

\section{HAL Id: hal-00762894 \\ https://hal.science/hal-00762894}

Submitted on 9 Dec 2012

HAL is a multi-disciplinary open access archive for the deposit and dissemination of scientific research documents, whether they are published or not. The documents may come from teaching and research institutions in France or abroad, or from public or private research centers.
L'archive ouverte pluridisciplinaire $\mathbf{H A L}$, est destinée au dépôt et à la diffusion de documents scientifiques de niveau recherche, publiés ou non, émanant des établissements d'enseignement et de recherche français ou étrangers, des laboratoires publics ou privés. 


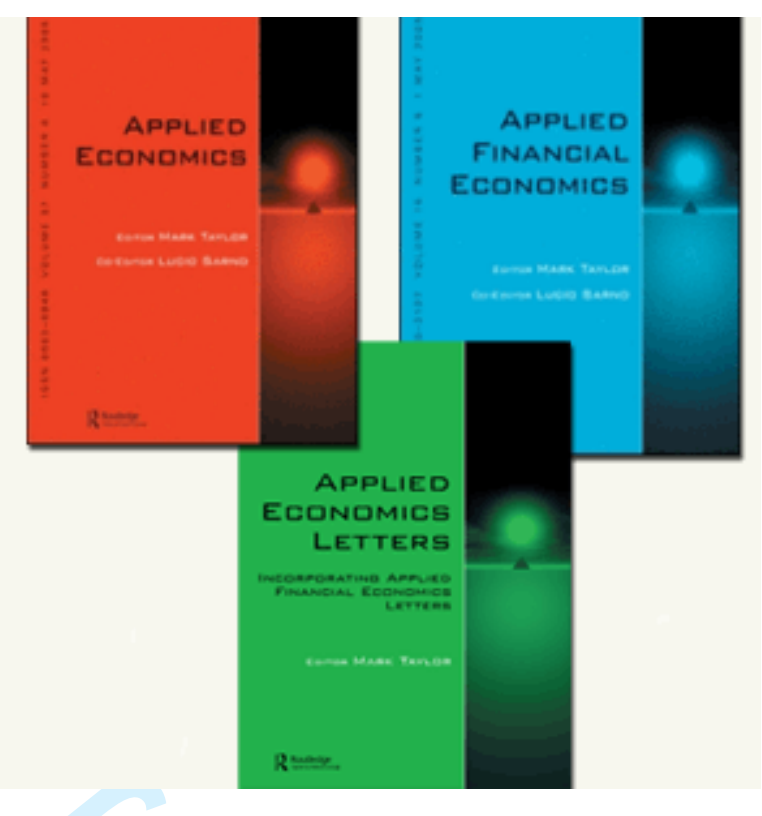

\section{"Compiling the Actuarial Balance for Pay-As-You-Go Pension Systems. Is it better to use the Hidden Asset or the Contribution Asset?"}

\begin{tabular}{|c|c|}
\hline Journal: & Applied Economics \\
\hline Manuscript ID: & APE-2010-0265.R1 \\
\hline Journal Selection: & Applied Economics \\
\hline $\begin{array}{r}\text { Date Submitted by the } \\
\text { Author: }\end{array}$ & 02-Apr-2011 \\
\hline Complete List of Authors: & $\begin{array}{l}\text { VIDAL-MELIA, CARLOS; UNIVERSITY OF VALENCIA, Department of } \\
\text { Financial Economics and Actuarial Science } \\
\text { BOADO-PENAS, MARIA CARMEN; KEELE UNIVERSITY, ECONOMICS }\end{array}$ \\
\hline JEL Code: & $\begin{array}{l}\text { H55 - Social Security and Public Pensions < H5 - National } \\
\text { Government Expenditures and Related Policies < H - Public } \\
\text { Economics, H83 - Public Administration < H8 - Miscellaneous Issues } \\
<\text { H - Public Economics, J26 - Retirement|Retirement Policies < J2 - } \\
\text { Time Allocation, Work Behavior, and Employment } \\
\text { Determination/Creation < J - Labor and Demographic Economics, } \\
\text { M49 - Other < M4 - Accounting and Auditing < M - Business } \\
\text { Administration and Business Econ; Marketing; Accounting }\end{array}$ \\
\hline Keywords: & Defined Benefits, Sweden, Transparency, USA \\
\hline
\end{tabular}




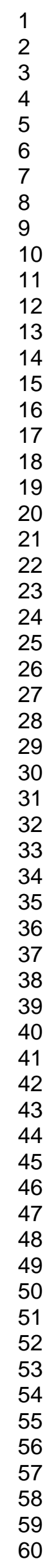

\section{SCHOLARONE ${ }^{m}$ \\ Manuscripts}

7

25

26

27

29

30

31

33

34

35

36

37

38

41

42

43

45

46

47

48

49

51

52

53

54

55

57

58

59

60 


\title{
"Compiling the Actuarial Balance for Pay-As-You-Go Pension Systems. Is it better to use the Hidden Asset or the Contribution Asset?"*
}

\author{
Carlos Vidal-Meliá and María del Carmen Boado-Penas \\ 02/04/2011 \\ ABSTRACT
}

\begin{abstract}
The aim of this paper is twofold: to establish the connection between the "contribution asset" (CA) and the "hidden asset" (HA) and to determine whether using either of them to compile the actuarial balance sheet in the pay-as-you-go (PAYG) pension system will provide a reliable solvency indicator. With these aims in mind, we develop a model based on those first put forward by Settergren and Mikula (2005) and Boado-Penas et al. (2008) to obtain the analytical properties of the CA and to confirm its soundness as a measure of the assets of a PAYG scheme. Our model also enables us to explore whether, and to what extent, the HA can be considered a second alternative measure of the assets for PAYG schemes. The main theoretical finding is that, despite their very different natures, the HA and the CA may nearly coincide at the limit when the interest rate of the financial market approaches the growth of the covered wage bill from above, but the HA supplies a solvency indicator which is not always consistent with the system's financial health.
\end{abstract}

(JEL: H55, H83, J26, M49).

Key words: Defined Benefits, Sweden, Transparency, USA.

\footnotetext{
* Carlos Vidal-Meliá and María del Carmen Boado-Penas are grateful for the financial assistance received from the Spanish Ministry of Science and Innovation project ECO2009-13616. We would also like to thank Salvador Valdés-Prieto, Robert Brown and Ole Settergren for their comments and suggestions, and Peter Hall for his English support. The comments and suggestions made by the journal's anonymous referees were especially helpful. Preliminary versions of this paper were presented at the International Congress of Actuaries (ICA 2010) in Cape Town (South Africa), at a scientific seminar organized by the Caisse des Dépôts in Bordeaux (France), and at a seminar organized by the University of Valencia (Spain). A previous version was published as a working paper by FUNCAS (Fundación de Cajas de Ahorro Confederadas). Financial support from FUNCAS is also gratefully acknowledged. Any errors are entirely due to the authors.

$\therefore$ Department of Financial Economics and Actuarial Science, University of Valencia, Avenida de los Naranjos, s.n. 46022 Valencia. (Spain). (e-mail: carlos.vidal@uv.es.).

t. (Corresponding author), Keele Management School, Keele University, Keele, Staffordshire ST5 5BG, UK. (e-mail: m.d.boado-penas@econ.keele.ac.uk.).
} 


\section{1.-Introduction}

The growing social demand for transparency in the financial management of public mandatory systems, the advantages of immunizing the pay-as-you-go (PAYG) system against some of the political risk it faces, and the desire to gain credibility among participants (contributors and pensioners) by reconciling their expectations to the economic realities of the pension plan all call for new management tools to be applied to the PAYG pension system.

Following Boado-Penas \& Vidal-Meliá (2011), there are basically two methodologies that can be used to compile an actuarial balance for the PAYG system: the "US" and the "Swedish" models. The "US" AB, published by the US Social Security Administration $(\mathrm{SSA})^{1}$, belongs to the aggregate or growth accounting models and measures the difference in present value - discounted by the projected yield on trust fund assets - between spending on pensions and income from contributions, expressed as a percentage of the present value of the contribution bases for a period of 75 years, taking into account that the level of financial reserves (trust fund) at the end of the time horizon reaches a magnitude of one year's expenditure.

The AB for the PAYG pension system as compiled in Sweden can be described as an actuarial statement listing the pension system's obligations towards contributors and pensioners at a particular date, with the amounts of the various assets which back up those commitments. It does not fit into any of the classical methods such as aggregate or growth accounting, micro-simulation, general equilibrium or indirect models. The Swedish balance sheet merits the term "actuarial" even more than the US balance. Although the Swedish balance follows the traditional structure of the accounting balance sheet deriving from principles of double-entry bookkeeping, it has a very strong actuarial profile as it includes its commitments to both pensioners and contributors as liabilities, while the US balance has a more financial profile as its commitments to contributors are not quantified until those contributors become pensioners ${ }^{2}$.

Particular reference is made in this paper to the "Swedish" model and, unless otherwise stated, the term 'actuarial balance' will refer to that model.

The entry on the PAYG balance sheet can be calculated following two different approaches: the "contribution asset" (CA) and the "hidden asset" (HA). The former has been studied by Settergren (2001, 2003), Settergren \& Mikula (2005), Boado-Penas et al. (2008) and the literature spawned by the Swedish Social Insurance Agency, while the latter has been analysed by Valdés-Prieto $(2002,2005)$ and Jackson $(2004)^{3}$, who are alone in suggesting its possible theoretical application to draw up the actuarial balance sheet. This concept is very close to what has been called the "hidden tax", the "implicit tax on pensions" and the "PAYG asset" by other researchers". As will be seen later, the CA uses for its calculation only factors that have an impact on the cash flows of the PAYG system

\footnotetext{
${ }^{1}$ See BOT (2010) for details.

${ }^{2}$ See the paper by Boado-Penas \& Vidal-Meliá (2011) for the main differences and similarities between both types of $\mathrm{AB}$ with regard to objectives, information provided, structure, projections, valuation of assets/revenues, discount rate, effects on contributors/pensioners, solvency/sustainability indicators, transparency and applicability.

${ }^{3}$ Jackson (2004) proposed a financial statement for US Social Security prepared in accordance with the principles of accrual accounting, and based on the so-called "quasi asset", an amount equal to the present value of excess revenues to be contributed by system participants over the additional benefits that they will accrue over the balance of their working lives.

${ }^{4}$ See the papers by Lüdecke (1988), Sinn (2000), Geanakoplos et al. (1998), Thogersen (2001), Lindbeck \& Persson (2003), Fenge \& Werding (2003, 2004), Disney (2004), Krieger (2005), Cigno (2008) and Robalino \& Bodor (2009) among others.
} 
and as a result needs no recourse to the interest rate of the financial market, whereas the HA, despite being applied to the PAYG system, must use the discount rate observed in the financial markets. As we will see in Section 2, it also has an important limitation: it only exists while the interest rate is greater than the internal rate of return of the PAYG system, and therefore it can only be calculated in dynamically efficient economies ${ }^{5}$.

The aim of this paper is twofold: to establish the connection between the CA and the HA and to determine whether using either of them to compile the actuarial balance sheet in PAYG systems will provide a reliable solvency indicator. As far as we are aware, there is a large gap in the literature which we are attempting fill with this paper because, until now, this area of study has not been looked at from the perspective of the connection between the CA and the HA as an entry to be included in the actuarial balance sheet.

Following this brief introduction, in Section 2 we analytically develop both the contribution asset and the hidden asset - taking into account possible increases or decreases in the number of contributors - and obtain the connection between the two. In Section 3 the concepts developed in Section 2 are applied to a complex example representative of the PAYG pension system using a number of reasonable hypotheses. This enables us to assess the reliability of the solvency indicator that appears when the actuarial balance is compiled. Section 4 lists the main conclusions reached. The paper ends with two appendices in which we show some numerical examples of the properties of the TD developed in Section 2.1, and we also present a sensitivity analysis of the numerical results shown in Section 3.

\section{2.-The contribution asset and the hidden asset.}

\section{1.- The contribution asset in DB PAYG systems.}

The contribution asset (CA) can be interpreted intuitively as the maximum level of liabilities that can be financed by the existing contribution rate without periodic supplements from the sponsor, if the conditions prevailing at the time of valuation remain constant. The value of the CA is the product of the turnover duration (TD) and the value of the contributions made in that period. The TD is the time expected to elapse from when a monetary unit enters the system as a contribution until it leaves in the form of a pension, assuming economic, demographic and legal conditions to be constant. This concept is based on population data obtained from a cross-section, not a projection.

In this section we develop the concept of the CA for the case where participants' lives last $\left(\mathrm{w}-1-\mathrm{x}_{\mathrm{e}}\right)$ periods, where ( $\left.\mathrm{w}-1\right)$ is the highest age to which it is possible to survive and $x_{e}$ is the age of entry into the system. In this case, A generations of contributors and (w$\left.1-\left(x_{e}+A\right)\right)$ generations of pensioners coexist at each moment in time.

We build on the case developed by Boado-Penas et al. (2008), where the contribution base (coinciding with earnings) grows at an annual real rate of g, i.e. zero inflation is assumed, but with the additional assumptions that the population increases or decreases over time ${ }^{6}$ at an annual accumulative rate of $\gamma$, affecting all groups of contributors equally, which means it must be assumed that real GDP and the system's income from contributions (the wage bill) also grows (decreases) at rate $G=(1+g)(1+\gamma)-1$, and pensions in payment increase or decrease at an annual rate of $\lambda$.

\footnotetext{
${ }^{5}$ An economy will suffer from dynamic inefficiency when the growth rate of GDP is equal to or greater than the risk-adjusted, long-term real rate of interest in the financial markets.

${ }^{6}$ The Swedish legislation implicitly assumes that population growth is $0(\gamma=0)$. Boado-Penas et al. (2008) use the same hypothesis. Here, as well as in Settergren \& Mikula (2005), both positive and negative population growth are allowed in the model.
} 
The parameters of the pension system are considered to be in a stationary state. Both the age giving entitlement to a retirement pension, " $\mathrm{x}_{\mathrm{e}}+\mathrm{A}$ ", and the formula used for calculating the pension are constant, leading to a fixed replacement rate of size $\beta$. is given by:

The demographic-financial structure at any moment " $\mathrm{t}$ " from the start of the system

1.-Age:

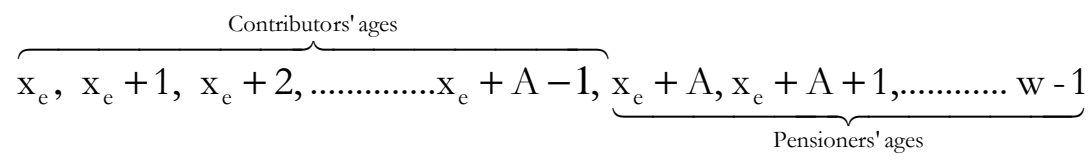

2.-Number of contributors by age at time t:

$$
\begin{aligned}
& \mathrm{N}_{\left(\mathrm{x}_{\mathrm{e}}, \mathrm{t}\right)}=\mathrm{N}_{\left(\mathrm{x}_{\mathrm{e}}, 1\right)}(1+\gamma)^{\mathrm{t}-1}, \\
& \mathrm{~N}_{\left(\mathrm{x}_{\mathrm{e}}+1, \mathrm{t}\right)}=\mathrm{N}_{\left(\mathrm{x}_{\mathrm{e}}+1,1\right)}(1+\gamma)^{\mathrm{t}-1} \\
& \mathrm{~N}_{\left(\mathrm{x}_{\mathrm{e}}+\mathrm{A}-1, \mathrm{t}\right)}=\mathrm{N}_{\left(\mathrm{x}_{\mathrm{e}}+\mathrm{A}-1,1\right)}(1+\gamma)^{\mathrm{t}-1}
\end{aligned}
$$

where $\mathrm{N}_{\left(\mathrm{x}_{\mathrm{e}}+\mathrm{k}, 1\right)}=\mathrm{N}_{\left(\mathrm{x}_{\mathrm{e}}, 1\right) \mathrm{k}} \mathrm{R}_{\mathrm{x}_{\mathrm{e}}}$, with ${ }_{\mathrm{k}} \mathrm{R}_{\mathrm{x}_{\mathrm{e}}}$ being the stable-in-time ratio between the number of individuals of age $x_{e}$ and $x_{e}+k$ years, which can be increasing or decreasing and can also be expressed by means of probabilities ${ }_{k} \mathrm{p}_{\mathrm{x}_{\mathrm{e}}}$.

3.-Average wage (average contribution base) by age at time t:

$$
\begin{aligned}
& y_{\left(x_{e}, t\right)}=y_{\left(x_{e}, 1\right)}(1+g)^{t-1}, \\
& y_{\left(x_{e}+1, t\right)}=y_{\left(x_{e}+1,1\right)}(1+g)^{t-1} \\
& \ldots \cdots \cdots \cdots \cdots \cdots \cdots \cdots \cdots \cdots \cdots \cdots \cdots \cdots \cdots \cdots \cdots \cdots \cdots \cdots \cdots \cdots \\
& y_{\left(x_{e}+A-1, t\right)}=y_{\left(x_{e}+A-1,1\right)}(1+g)^{t-1}
\end{aligned}
$$

The demographic structure above means that the age-wage structure (contribution bases) only undergoes proportional changes. The slope of the age-wage structure is constant.

The annual retirement pension is $\beta \cdot Y_{C, 0}$, a set percentage of average wages taking into account all the years (A) contributed, $Y_{C, 0}=\frac{\sum_{k=0}^{A-1} y_{\left(x_{e}+k,-A+k+1\right)}}{A}$. It will also be assumed that payment of both contributions and benefits is distributed uniformly over time.

In this scenario, the stability of the contribution rate $(\theta)$ that ensures equality between contribution revenue and pension expenditure depends on the stability of the dependency ratio $(\mathrm{dr})$. The contribution rate from year " $\mathrm{w}-\mathrm{x}_{\mathrm{e}} \mathrm{-} \mathrm{A}=\mathrm{t}$ " counting from the start of the system can be considered constant from the actuarial point of view because from that moment the ratio between the number of pensioners and the number of contributors - 
$(\mathrm{dr})$ - stabilizes:

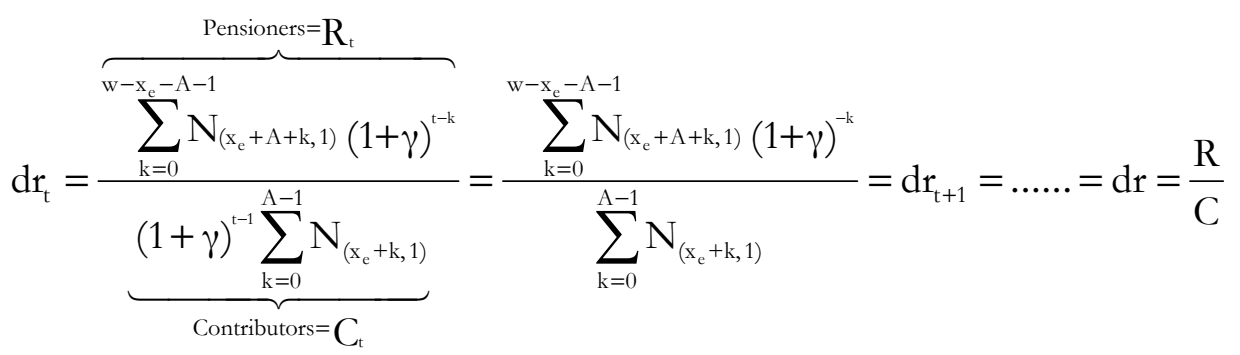

because both groups evolve (increase or decrease) exactly equal to rate $\gamma$. From this year the system is in a stationary state and the contribution rate will be:

$$
\theta_{\mathrm{t}}=\frac{\overbrace{\beta Y_{C, 0} \underbrace{\sum_{\mathrm{k}=0}^{\mathrm{w}-\mathrm{x}_{\mathrm{e}}-\mathrm{A}-1} \mathrm{~N}_{\left(\mathrm{x}_{\mathrm{e}}+\mathrm{A}+\mathrm{k}, 1\right)}(1+\mathrm{G})^{\mathrm{t}-1-\mathrm{k}}(1+\lambda)^{\mathrm{k}}}_{\text {Contribution base }}}^{\text {Expenditure on pensions }}}{\underbrace{(1+G)^{\mathrm{t}-1} \sum_{\left(\mathrm{x}_{\mathrm{e}}+\mathrm{k}, 1\right)}^{\mathrm{A}-1} \mathrm{~N}_{\left(\mathrm{x}_{\mathrm{e}}+\mathrm{k}, 1\right)}}_{\mathrm{k}=0}}=\frac{\mathrm{P}_{\left(\mathrm{x}_{\mathrm{e}}+\mathrm{A}, \mathrm{t}\right)} \sum_{\mathrm{k}=0}^{\mathrm{w}-\mathrm{x}_{\mathrm{e}}-\mathrm{A}-1} \mathrm{~N}_{\left(\mathrm{x}_{\mathrm{e}}+\mathrm{A}+\mathrm{k}, \mathrm{t}\right)}\left[\frac{1+\lambda}{1+\mathrm{G}}\right]^{\mathrm{k}}}{\sum_{\mathrm{k}=0}^{\mathrm{A}-1} \mathrm{y}_{\left(\mathrm{x}_{\mathrm{e}}+\mathrm{k}, \mathrm{t}\right)} \mathrm{N}_{\left(\mathrm{x}_{\mathrm{e}}+\mathrm{k}, \mathrm{t}\right)}}=\theta_{\mathrm{t}+1}=. .=\theta
$$

[5.]

If the system's average pension is considered to be:

$$
\bar{P}_{t}=\frac{\overbrace{\beta Y_{C, 0} \sum_{k=0}^{w-x_{e}-A-1} N_{\left(x_{e}+A+k, 1\right)}(1+g)^{t-1-k}(1+\gamma)^{t-1-k}(1+\lambda)^{k}}^{\text {Expenditure on pensions }}}{\underbrace{\sum_{k=0}^{w-x_{e}-A-1} N_{\left(x_{e}+A+k, 1\right)}(1+\gamma)^{t-1-k}}_{\text {Pensioners }=R_{t}}}=\frac{P_{\left(x_{e}+A, t\right)} \sum_{k=0}^{w-x_{e}-A-1} N_{\left(x_{c}+A+k, t\right)}\left[\frac{1+\lambda}{1+G}\right]^{k}}{\sum_{k=0}^{w-x_{c}-A-1} N_{\left(x_{e}+A+k, t\right.}(1+\gamma)^{-k}}
$$

with:

$$
\mathrm{P}_{\left(\mathrm{x}_{\mathrm{e}}+\mathrm{A}, \mathrm{t}\right)}=\beta \mathrm{Y}_{\mathrm{C}, 0}(1+\mathrm{g})^{\mathrm{t}-1}
$$

and the average contribution base being:

$$
\overline{\mathrm{W}}_{\mathrm{t}}=\frac{\overbrace{(1+\mathrm{G})^{\mathrm{t}-1} \sum_{\mathrm{k}=0}^{A-1} \mathrm{y}_{\left(\mathrm{x}_{\mathrm{e}}+\mathrm{k}, 1\right)} \mathrm{N}_{\left(\mathrm{x}_{\mathrm{e}}+\mathrm{k}, 1\right)}}^{\text {Aggregate contribution base }}}{\underbrace{(1+\gamma)^{t-1} \sum_{\mathrm{k}=0}^{A-1} \mathrm{~N}_{\left(\mathrm{x}_{\mathrm{e}}+\mathrm{k}, 1\right)}}_{\text {Contributors }=\mathrm{C}_{\mathrm{t}}}}=\frac{\sum_{\mathrm{k}=0}^{A-1} \mathrm{y}_{\left(\mathrm{x}_{\mathrm{e}}+\mathrm{k}, \mathrm{t}\right)} \mathrm{N}_{\left(\mathrm{x}_{\mathrm{e}}+\mathrm{k}, \mathrm{t}\right)}}{\sum_{\mathrm{k}=0}^{A-1} \mathrm{~N}_{\left(\mathrm{x}_{\mathrm{e}}+\mathrm{k}, \mathrm{t}\right)}}
$$

in the stationary state reached, the average pension-average contribution base quotient is already constant due to the fact that the numerator and denominator evolve equally (at the rate of variation in wages): 


$$
\frac{\overline{\mathrm{P}}_{\mathrm{t}}}{\overline{\mathrm{W}}_{\mathrm{t}}}=\frac{\overline{\mathrm{P}}_{\mathrm{t}+1}}{\overline{\mathrm{W}}_{\mathrm{t}+1}}=\ldots \ldots=\frac{\overline{\mathrm{P}}}{\overline{\mathrm{W}}}
$$

Therefore the contribution rate that ensures equality between revenue and expenditure is the product of the demographic dependency ratio and the financial ratio (the system's average replacement rate):

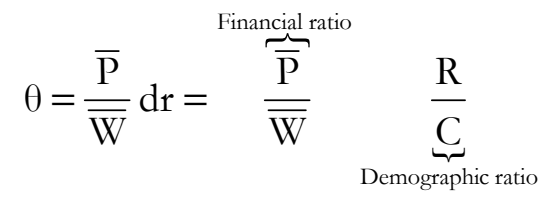

The system's liabilities, $\mathrm{V}^{\mathrm{T}}$, have two components: (i) liabilities to current pensioners $\mathrm{V}^{\mathrm{r}}$, and (ii) liabilities to current contributors $\mathrm{V}^{\mathrm{c}}$. Actuaries use the terms "technical provisions for pensions in payment" and "technical provisions for rights being acquired" for (i) and (ii) respectively. equal to:

The first component - liabilities to current pensioners - in the stationary state is

$$
\begin{gathered}
V_{t}^{\mathrm{r}}=\beta Y_{C, 0} \sum_{\mathrm{k}=0}^{\mathrm{w}-\mathrm{xe}-\mathrm{A}-1} \mathrm{~N}_{\left(\mathrm{x}_{\mathrm{e}}+\mathrm{A}+\mathrm{k}, 1\right)} \ddot{\mathrm{a}}_{\mathrm{x}_{\mathrm{e}}+\mathrm{A}+\mathrm{k}}^{\lambda}(1+\mathrm{G})^{\mathrm{t}-1-\mathrm{k}}(1+\lambda)^{\mathrm{k}} \\
= \\
\mathrm{P}_{\left(\mathrm{x}_{\mathrm{e}}+\mathrm{A}, \mathrm{t}\right)} \sum_{\mathrm{k}=0}^{\mathrm{w}-\mathrm{xe}-\mathrm{A}-1} \mathrm{~N}_{\left(\mathrm{x}_{\mathrm{e}}+\mathrm{A}+\mathrm{k}, \mathrm{t}\right)} \ddot{\mathrm{a}}_{\mathrm{x}_{\mathrm{e}}+\mathrm{A}+\mathrm{k}}^{\lambda}\left[\frac{1+\lambda}{1+\mathrm{G}}\right]^{\mathrm{k}}
\end{gathered}
$$

with $\ddot{a}_{\mathrm{x}_{\mathrm{c}}+\mathrm{A}+\mathrm{k}}$ being the present value of a lifetime annuity due of 1 monetary unit per year payable in advance and growing at real rate $\lambda$, valued at age " $x_{e}+A+k$ " years, with a technical interest rate equal to $\mathrm{d}=\mathrm{G}$.

The second component is the liability to current contributors, payments to whom have still not begun but for which a commitment has been made by virtue of the contributions already paid. This second component of the liabilities is calculated by the prospective method ${ }^{7}$ and will be the difference between the present value of future pensions and the present value of future contributions. The definition of these liabilities is that of the "closed group".

Liabilities to contributors will be constant and equal to:

\footnotetext{
7 The calculation is much simpler in the notional accounts system and the logical thing is to use the retrospective system, the value of which coincides with the sum of the notional capital accumulated by the contributors as a whole.
} 


$$
\overbrace{\mathrm{P}_{\left(\mathrm{x}_{\mathrm{c}}+\mathrm{A}, \mathrm{t}\right)} \mathrm{N}_{(\mathrm{xc}+\mathrm{A}, \mathrm{t})} \ddot{a}_{\mathrm{x} c+\mathrm{A}}^{\lambda} \sum_{\mathrm{h}=1}^{\mathrm{A}}\left[\frac{1+\mathrm{G}}{1+\mathrm{d}}\right]^{\mathrm{h}}}-\underbrace{\theta \sum_{\mathrm{k}=0}^{\mathrm{A}-1} \sum_{\mathrm{h}=0}^{\mathrm{k}} \mathrm{N}_{(\mathrm{xc}+\mathrm{k}, \mathrm{t})} \mathrm{y}_{(\mathrm{xc}+\mathrm{k}, \mathrm{t})}\left[\frac{1+\mathrm{G}}{1+\mathrm{d}}\right]^{\mathrm{h}}}_{\text {Future contributions }}
$$

To obtain the TD in the financially sustainable PAYG system, the total expected liabilities are divided by the annual contribution flow, and the interest rate for discounting future pensions and contributions is taken to be the IRR, i.e. the real growth in wages plus the real growth in the contributing population - which is actually $G=(1+g)(1+\gamma)-1)^{8}$ - and therefore:

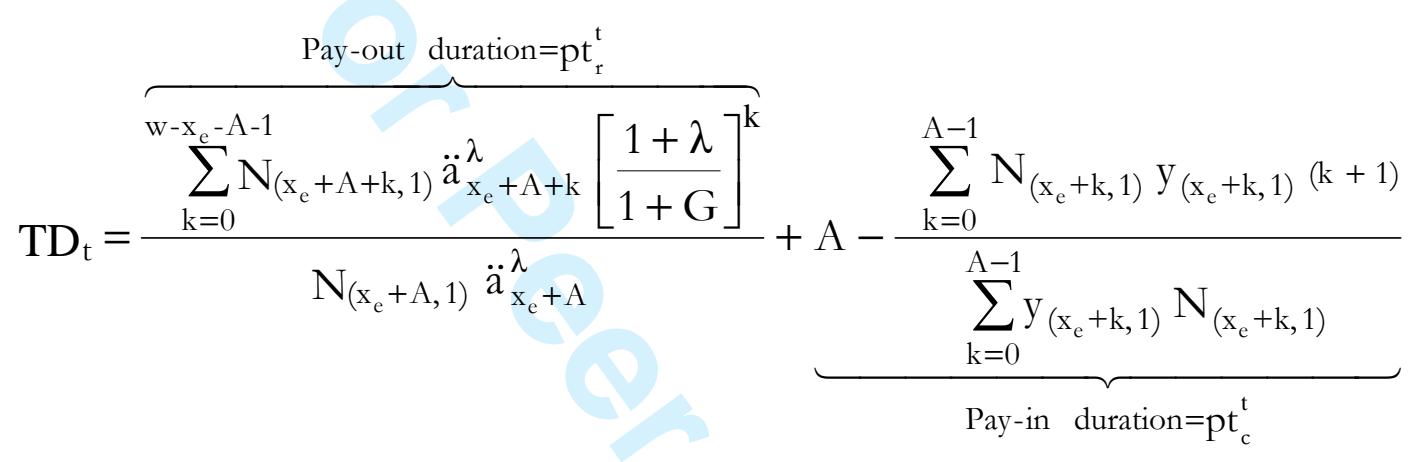

where the $\mathrm{TD}_{\mathrm{t}}$ can also be expressed as':

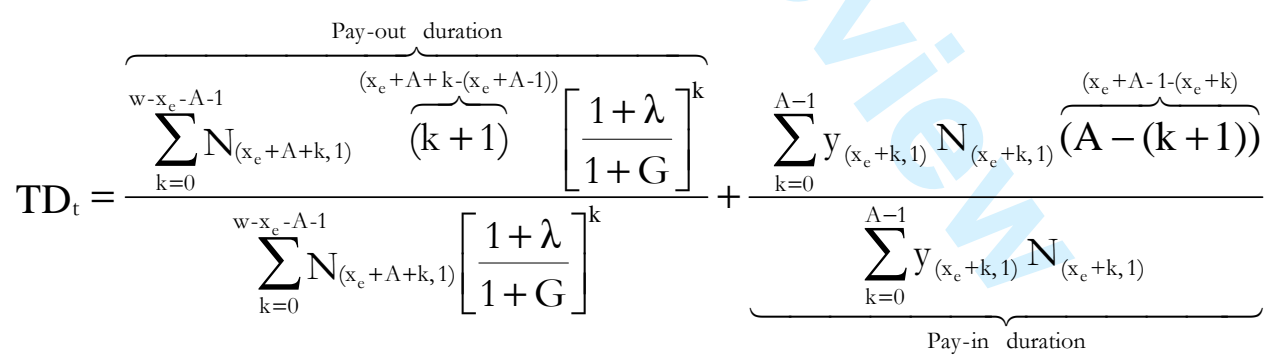

where the pay-in duration - the average length of stay in the entry flow - is the average time in years that the monetary unit is expected to form part of the liability to contributors before it becomes part of the liability to pensioners. The pay-out duration or average length of stay in the exit flow is the number of years that the monetary unit is expected to form part of the liability to pensioners before leaving in the form of benefit payments.

\footnotetext{
${ }^{8}$ See the paper by Boado-Penas \& Vidal-Meliá (2010). Gronchi \& Nisticò (2008) present a reformulation of the Samuelson-Aaron theorem that recognized the wage bill growth rate as the IRR on contributions and the 'sustainable return' of PAYG defined-benefit schemes in a steady growing economy. Knell's papers (2005a, 2005b) are also very useful.

${ }^{9}$ This is similar to the formula used in the report by the Swedish authorities to calculate the real balance. See the Orange Annual Report 2009.
} 
The TD is the time expected to elapse between a monetary unit entering the system as a contribution and leaving in the form of a pension, assuming economic, demographic and legal conditions to be constant, i.e. the time in years that is expected to elapse before all the system's liabilities are renewed or rotated.

$$
\frac{\mathrm{V}_{\mathrm{t}}^{\mathrm{T}}}{\mathrm{C}_{\mathrm{t}}} \equiv \mathrm{TD}_{\mathrm{t}}=\mathrm{pt}_{\mathrm{r}}^{\mathrm{t}}+\mathrm{pt}_{\mathrm{c}}^{\mathrm{t}}
$$

If " $\mathrm{x}_{\mathrm{e}}+\mathrm{A}-1$ " years are added to and subtracted from the above expression, the TD is the difference in weighted average ages of pensioners and contributors:

$$
\begin{aligned}
& \text { Weighted average age for the pensioners }=\mathrm{A}_{\mathrm{r}}^{\mathrm{t}} \\
& \mathrm{TD}_{\mathrm{t}}=\overbrace{\left(\mathrm{x}_{\mathrm{e}}+\mathrm{A}-1\right)+\mathrm{pt}_{\mathrm{r}}^{\mathrm{t}}}-\underbrace{}_{\left(\mathrm{x}_{\mathrm{e}}+\mathrm{A}-1-\mathrm{pt}_{\mathrm{c}}^{\mathrm{t}}\right)} \\
& \text { Weighted average age for the contributors }=A_{c}^{t}
\end{aligned}
$$

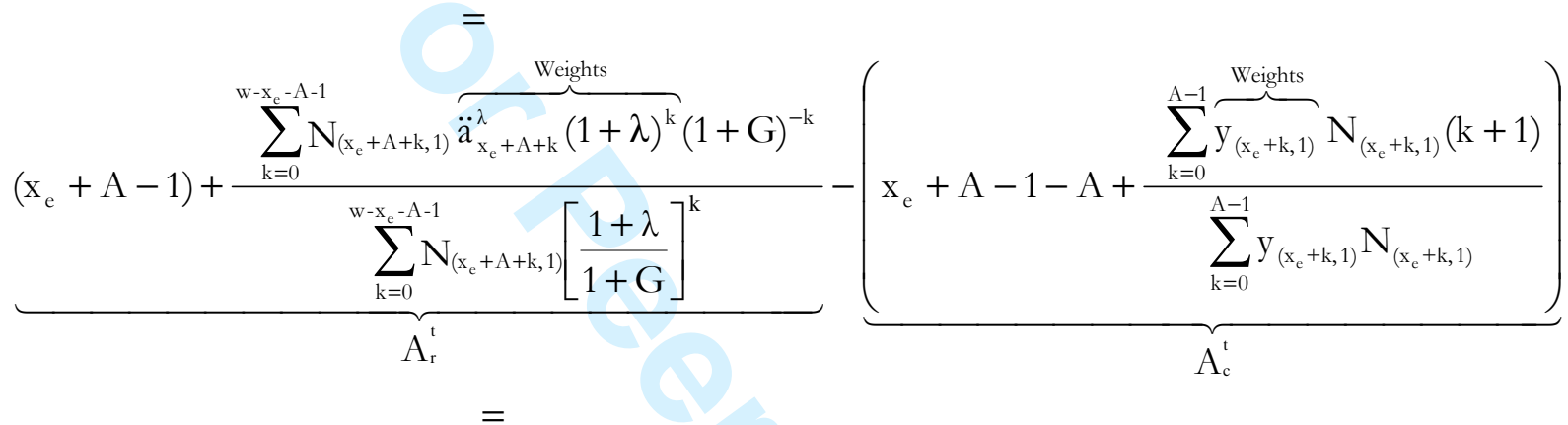

$$
\begin{aligned}
& \underbrace{\frac{\sum_{k=0}^{w-x_{e}-A-1} N_{\left(x_{e}+A+k, 1\right)}\left(x_{e}+A+k\right)\left[\frac{1+\lambda}{1+G}\right]^{k}}{\sum_{k=0}^{k} N_{\left(x_{e}+A+k, 1\right)}\left[\frac{1+\lambda}{1+G}\right]^{k}}}_{A_{r}^{t}}-\underbrace{\sum_{k=0}^{k-x_{e}-A-1} y_{\left(x_{e}+k, 1\right)} N_{\left(x_{e}+k, 1\right)}^{A-1} y_{\left(x_{e}+k, 1\right)} N_{\left(x_{e}+k, 1\right)}\left(x_{e}+k\right)}_{A_{c}^{t}}
\end{aligned}
$$

It must be stressed that the TD in this theoretical model, irrespective of the IRR $=\mathrm{G}$ used to discount the pensions and contributions, is always equal to the difference in expected weighted average ages of contributors $A_{c}^{t}$ and pensioners $A_{r}^{t}$.

As deduced from the process, the $\mathrm{TD}_{\mathrm{t}}$ is interpreted as the number of years expected to elapse for the committed liabilities with contributors and pensioners to be completely renewed at the current level of contributions, since it is established that the system is in a stationary state and every year pension spending is paid for with the income from contributions.

Each monetary unit (see Formula 16) enters the system as if it were paid by a contributor of " $\mathrm{A}_{\mathrm{c}}$ " years and remains within the contribution liability until retirement age is reached (pay-in), and is received by the pensioner of " $\mathrm{A}_{\mathrm{r}}$ " years after remaining within the liability to pensioners during the pay-out. 
So as to avoid inexact interpretations ${ }^{10}$ which distort the concept, the $\mathrm{TD}_{\mathrm{t}}$ can also be expressed as:

$$
\mathrm{TD}_{\mathrm{t}}=\overbrace{\left(\mathrm{x}_{\mathrm{e}}+\mathrm{A}\right)}^{\text {Age of retirement }}-\underbrace{\underbrace{\text { Normalized }}_{\left(\mathrm{A}_{\mathrm{c}}^{\mathrm{t}}-\mathrm{pt} \mathrm{t}_{\mathrm{r}}^{\mathrm{t}}+1\right)}}_{\mathrm{A}_{\mathrm{c}}^{*}}
$$

Finally, the CA is the product of the system's TD for yearly contributions:

$$
\mathrm{CA}_{\mathrm{t}}=\underbrace{\mathrm{C}_{\mathrm{t}} * \underbrace{\left(\mathrm{A}_{\mathrm{r}}^{\mathrm{t}}-\mathrm{A}_{\mathrm{c}}^{\mathrm{t}}\right)}_{\mathrm{TD}_{\mathrm{i}}}}_{\text {Contribution asset }}=\overbrace{\mathrm{V}_{\mathrm{t}}}^{\text {Liabilities }}=\mathrm{C}_{\mathrm{t}} *\left(\mathrm{pt}_{\mathrm{r}}^{\mathrm{t}}+\mathrm{pt}_{\mathrm{c}}^{\mathrm{t}}\right)
$$

In a theoretical model such as the one suggested, actuarially balanced and in an initial stationary state, the value of the TD, under variations of the system's parameters, has the following properties in a new steady state:

1.-For a value of $\gamma$ (growth rate of population) constant, the TD remains constant as long as it is considered that $\mathrm{g}$ (growth rate of contribution base) is equal to $\lambda$ (growth rate of pensions in payment), as can be seen in the first term (pay-out) of Expression 14, whereas the second term (pay-in) remains constant even though there are changes in the value of these parameters. It is important to stress that although the TD and the dependency rate do not change, there are changes in the amount of the pensions awarded by the system, in the contribution rate and, obviously, in the system's assets and liabilities in a balanced state.

2.-The TD, for a value of $\gamma$ constant, depends on the difference $\mathrm{g}-\lambda$ (decreasing as this difference grows), as can be deduced from the first term (pay-out) of Expression 14. In fact the TD increases or decreases because the expected weighted average age of the pensioners changes. The expected age of the contributors remains the same (second term of Expression 16).

3.-The TD for a value of $\lambda$ and $g$ without changes decreases as $\gamma$ increases and vice versa and the expected weighted average age of the pensioners is reduced (or increased), although there are changes in the amount of the pensions awarded by the system, in the contribution rate and in the system's assets and liabilities in a balanced state.

4.-For a value of $\lambda=$ constant, the TD remains constant as long as $(1+\mathrm{g})(1+\gamma)-1=$ constant., as can be deduced from the first term (pay-out) of Expression 14. In this assumption the contribution rate in a balanced state will also remain constant, although there will be variations in the dependency rate (Expression 4) and in the system's average contribution-average pension ratio (Expressions 6 and 8).

5.-The TD decreases (increases) with increases (decreases) in the slope of the age-wage structure, as can be deduced from the second term (pay-in) of Expression 14. In fact the TD increases or decreases because the expected weighted average age of the contributors changes, while that of the pensioners remains the same (first term of Expression 14). In this assumption the dependency rate in a balanced state remains constant, although there will be variations in the contribution rate (Formula 5) and in the system's average contribution-average pension ratio.

\footnotetext{
${ }^{10}$ See the paper by Andrews (2008), page 70 .
} 
6.-The TD increases (decreases) when there are increases (decreases) in longevity - as can be seen in Expression 14 - as there is an increase (decrease) in the pay-out. Clearly the increase (decrease) in longevity increases (decreases) the contribution rate for a balanced state and the system's assets and liabilities" ${ }^{11}$.

7.-V ariations in retirement age. An increase (decrease) in retirement age would be expected to increase (decrease) the expected weighted average age of pensioners and contributors (Expression 16). The combined effect on the TD would also depend on all the other parameters that affect the pension system, such as the salary profile and the mortality pattern.

8.-Variations in the number of generations of contributors for a particular retirement age. An increase (decrease) in the number of generations of contributors (second term of Equation 14) would be expected to increase (decrease) the TD because the weighted average age of the contributors would decrease (increase), although clearly both the contribution rate for a balanced state and the contributor-pensioner ratio would have to increase (decrease).

9.-V ariations in the number of generations of pensioners for a particular retirement age. An increase (decrease) in the number of generations of pensionersfirst term of Equation 14) would be expected to increase (decrease) the TD because the weighted average age of the pensioners would increase (decrease), although clearly both the contribution rate for a balanced state and the pensioner-contributor ratio would have to increase (decrease). Naturally this is similar to the variations in longevity.

Appendix 1 shows some numerical examples of the properties of the TD developed above.

\section{2.-The hidden asset in DB PAYG systems.}

According to Valdés-Prieto (2002), the hidden asset (HA) is the present expected value of the hidden taxes that the system will apply to its participants in the future, either in the form of excess contributions in relation to the pensions to be provided or in the form of insufficient pensions in relation to the contributions paid. Hidden taxes are defined as contributions in excess of those that would be needed by a capitalized system to pay the same benefits. Their existence stems from the theoretical assumption that contributions should yield the interest rate of the financial market and that the economy suffers no dynamic inefficiency. Theoretical macroeconomic equilibrium stipulates that $r>G$, both in the specific cases of certainty as shown by Tirole (1985), and uncertainty, following Demange (2002) and Krueger \& Kubler (2006).

If the concept of the HA is developed, when " $\mathrm{w}-\mathrm{x}_{\mathrm{e}}-\mathrm{A}=\mathrm{t}$ " years have passed since the inception of the system, the concept can be generalized and it can also be shown that the $\mathrm{HA}$ and the CA become nearly equal under certain circumstances.

It is assumed that the covered wage bill of the pension system grows at a real annual rate of $G$, where $G=(1+g)(1+\gamma)-1$, according to the notation used in the previous section.

This would give:

\footnotetext{
${ }^{11}$ This explains Robalino \& Bodor's (2009) objections regarding the TD: "the TD can increase as a result of an increase in life expectancy and that would be perceived as an increase in contribution assets when in fact that increase can reduce the pay-as-you-go asset as individuals receive pensions for longer". The truth is that the TD is not an isolated element within the pension system. It is related to the other parameters too.
} 


$$
\mathrm{HA}_{\mathrm{t}} \equiv \sum_{\mathrm{i}=0}^{\infty}\left[\sum_{\mathrm{k}=0}^{\mathrm{A}-1} \theta^{*} \cdot \mathrm{y}_{\left(\mathrm{x}_{\mathrm{e}}+\mathrm{k}, \mathrm{t}\right)} \cdot \mathrm{N}_{\left(\mathrm{x}_{\mathrm{e}}+\mathrm{k}, \mathrm{t}\right)}\right]\left[\frac{1+\mathrm{G}}{1+\mathrm{r}}\right]^{\mathrm{i}}=\theta^{*} \sum_{\mathrm{k}=0}^{\mathrm{A}-1} \mathrm{y}_{\left(\mathrm{x}_{\mathrm{e}}+\mathrm{k}, \mathrm{t}\right)} \cdot \mathrm{N}_{\left(\mathrm{x}_{\mathrm{e}}+\mathrm{k}, \mathrm{t}\right)}\left[\frac{1+\mathrm{r}}{\mathrm{r}-\mathrm{G}}\right]
$$

where $\theta^{*}=\left(\theta-\theta_{\mathrm{f}}\right)$ is the excess contribution rate that the system has to apply in perpetuity to its contributors, over the actuarially fair rate $\theta_{\mathrm{f}}$, in order to remain financially solvent. In Formula 19, it seems clear that the biggest difficulty is in setting the value of $\theta_{\mathrm{f}}$ depending on the $\mathrm{r}$ considered.

Given that in a system in a stationary state and actuarially balanced, as shown earlier, the contribution asset is equal to the liability, the hidden asset must in the same way be equal to the system's total liability valued with discount rate $r$. The actuarially fair rate that makes $\mathrm{HA}_{\mathrm{t}}=\mathrm{V}_{\mathrm{t}}^{\mathrm{T}(\mathrm{r}>\mathrm{G})}$ is:

$$
\theta_{\mathrm{f}}=\left(\theta-\frac{\overbrace{\sum_{\mathrm{t}=0}^{\mathrm{T}(\mathrm{r}>\mathrm{G})}\left[\frac{\mathrm{r}-\mathrm{G}}{1+\mathrm{r}}\right]}^{\text {Perpetual excess contribution rate }} \mathrm{y}_{\left(\mathrm{x}_{\mathrm{e}}+\mathrm{k}, \mathrm{t}\right)} \cdot \mathrm{N}_{\left(\mathrm{x}_{\mathrm{e}}+\mathrm{k}, \mathrm{t}\right)}}{\mathrm{A}^{\mathrm{A}-1}}\right.
$$

It can be seen that the excess contribution that has to be paid every year in perpetuity by all contributors is to cover that part of the liability ${ }^{12}$ deriving from those affiliates who received payments without having made any contributions or without having paid them in full but who benefited from a higher IRR than other generations ${ }^{13}$ (in the first year the system started there were already beneficiaries who had not paid contributions, and in the second year those who received a pension had only contributed for one year and received a full pension. Only when A years had passed would all beneficiaries have a full contribution record):

$$
\overbrace{\theta^{*} \sum_{\mathrm{k}=0}^{\mathrm{A}-1} \mathrm{y}_{\left(\mathrm{x}_{\mathrm{e}}+\mathrm{k}, \mathrm{t}\right)} \cdot \mathrm{N}_{\left(\mathrm{x}_{\mathrm{e}}+\mathrm{k}, \mathrm{t}\right)}^{\text {Excess yearly contributions }}}=\underbrace{\mathrm{V}_{\mathrm{t}}^{\mathrm{T}(\mathrm{r}>\mathrm{G})}\left[\frac{\mathrm{r}-\mathrm{G}}{1+\mathrm{r}}\right]}_{\text {Pepertual interest cost acrued by actuarial liabilities }}
$$

It is therefore consistent that the excess contribution should be discounted from the contribution rate needed to balance the system in order to obtain the actuarially fair contribution rate in line with the performance of the financial market.

In the stationary state described and with an actuarially-balanced system, if it is considered that $r>G$, it can be stated that:

$$
\left(C A_{t}=V_{t}^{T(r=G)}\right)>\left(H A_{t}=V_{t}^{T(r>G)}\right)
$$

\footnotetext{
${ }^{12}$ Note that this part of the liability can be minimized if it is considered that during the first A years the affiliates who start to receive a pension receive only a fraction of the replacement rate $\beta \cdot y(c, k-1))^{*}(\mathrm{k} / \mathrm{A})$ depending on the years contributed by their generation $(\mathrm{k})$. Only those who contribute over their whole working life will receive the full amount.

13 See the paper by Boado-Penas \& Vidal-Meliá (2010).
} 
and it is also clear that as the difference $r-G$ is reduced, the value of the HA will move closer towards the value of the $C A$, and at the limit where $r$ tends upwards towards $G^{14}$, the difference between those values tends to zero given that the value of their liabilities becomes nearly equal:

$$
\lim _{(\mathrm{r}-\mathrm{G}) \rightarrow 0^{+}}\left(C A_{t}-H A_{t}\right)=\left(V_{t}^{T(r=G)}-V_{t}^{T\left((r-G) \rightarrow 0^{+}\right)}\right) \cong 0
$$

and, in this case, $\theta_{\text {eq }}=\theta \cong \theta_{\mathrm{f}}$.

\section{3.-The contribution asset and the hidden asset as items to be integrated into the "Swedish" actuarial balance.}

This subsection summarizes the two previous ones by comparing the main elements that characterize the CA and the HA as items to be integrated into the "Swedish" actuarial balance. The main economic implications will then be discussed.

The $\mathrm{CA}$ is the maximum liability that can be financed in the long term by the present contribution without requiring additional funding from the promoter, assuming a stationary state. The HA is defined as the present value of the hidden taxes or subsidies ${ }^{15}$ that the system will have to apply to its contributors in the future, within legislated parameters and with trends known. These hidden taxes in turn are defined as the contributions in excess of those that would be needed by a capitalized system to pay the same benefits.

The basis of each concept is different. The CA is based on the turnover duration (TD) and is the product of the annual contributions multiplied by the difference between the expected weighted average age of pensioners, $A_{r}^{t}$, and contributors, $A_{c}^{t}$. In practice, Boado-Penas et al (2009), if the population declines (increases), there is a risk that the accounts will (slightly) overstate (understate) the system's assets in relation to its liabilities, since in such a case the turnover duration is (slightly) overestimated (underestimated). However, as the balance sheet must be compiled every year according to verifiable events and transactions, it tends to provide a true and fair view. The stationary demographic and economic state is certainly not ex-post facto true, but because successive changes are included as they are registered in successive balance sheets, the solvency indicator remains reliable ${ }^{16}$. Another requirement for calculating the TD is that the only contingency assessed is retirement. Other contingencies such as invalidity or survivor benefit make it more difficult to define the TD in both theoretical and practical terms.

The HA is based on the theoretical assumption that contributions should yield a return at the interest rate of the financial market (relating the PAYG system to the capitalization system), that the economy does not suffer from dynamic inefficiency ( $G \geq r$ ), and that the excess contribution to be paid every year in perpetuity by all contributors is allocated (Equation 21) to cover that part of the liability deriving from those affiliates who received pensions without having made any contributions or without having paid them in full but who benefited from a greater IRR than all the other generations.

\footnotetext{
${ }^{14}$ It should be remembered that the function of the "hidden asset" is discontinuous and indeterminate for $r=G$, and its value tends towards less than infinite when $r$ tends towards $G$ on the left.

${ }^{15}$ The subsidies could originate in the form of insufficient contributions in relation to the pensions to be received.

${ }^{16}$ See the papers by Auerbach \& Lee (2009a and 2009b).
} 
The relation that both these assets have with the system's liabilities is also different. In order for it to be consistent with the CA, the system's actuarial liability has to be calculated with the rate of return of the PAYG system, which is assumed to be $G=$ $(1+g)(1+\gamma)-1$. The actuarial liability will be greater than that of the capitalization system if the hypothesis of dynamic efficiency is fulfilled. And on the practical side, both the assets and the liabilities are valued on the basis of verifiable cross-section facts, i.e. no projections are made ${ }^{17}$. For example, current longevity is used even though it is expected to increase. If and when that expectation materializes in new mortality tables, this will be incorporated into the information on the balance sheet on a year-to-year basis

In the case of the HA, for consistency the system's actuarial liability has to be calculated using the rate of return of the financial market, $r$. Unlike in the previous case, the actuarial liability would coincide with the liability there would be if the pension system were funded by capitalization. It seems clear that the liability calculated with either $G$ or $r$ answers two different questions: 'What is the value of the commitment to contributors and pensioners taken on by the system?', for the liability calculated with $G$, and 'How much would the system have to pay a third party if it decided to contract out or transfer its commitments to contributors and pensioners?', if the liability was calculated with $\mathrm{r}$.

There are also differences in the practical application of both concepts. The CA, Försäkringskassan (2010), is applied in order to compile the actuarial balance for Swedish Social Security, which has a DC PAYG pension system (NDC), and is fairly straightforward to calculate as it needs no projections of economic, demographic or financial variables.

The HA, however, has only a theoretical application so far. Apart from the difficulty in setting the value of $r$, it needs projections of economic, demographic and financial variables in order to be calculated. Most authors that have used the concept have not suggested that it be used to compile actuarial balances. Disney (2004), for example, constructs indicators of the tax component of pension programmes, both between and within generations, across a range of OECD countries and time periods, and Fenge \& Werding (2004) use the concept of the implicit tax rate" to measure intergenerational imbalances in unfunded public pension schemes.

However, although their analytical expressions appear to be somewhat different, their structures are based on the taxable wage bill, a financial and multiplying effect ${ }^{18}$, and three contribution rates. For the CA:

$$
C A_{t}=[\underbrace{\theta}_{\text {Rate of contribution }} \overbrace{\left(A_{r}^{t}-A_{c}^{t}\right)}^{\text {Financial factor }}][\underbrace{\sum_{k=0}^{A-1} y_{\left(x_{c}+k, t\right)} N_{\left(x_{c}+k, t\right)}}_{\text {Aggregate contribution base }}]
$$

while for the HA it is:

\footnotetext{
${ }^{17}$ It would be necessary to make projections for the DB PAYG pension system as liabilities to contributors have to be calculated using the prospective method.

18 According to Settergren (2003), the TD can be interpreted as the value supplied by discounting a perpetual flow of contributions, where the discount factor is the inverse of the TD. For example, if the value of the TD is 33 years, the CA is calculated by discounting a perpetual (yearly) contribution with an interest rate of $3.03 \%$.
} 
and as we saw in the previous subsection, since the difference $r-G$ is reduced, the value of the HA moves closer to the value of the $C A$, and at the limit when $r$ tends towards $G$ and upwards, the values of both virtually coincide, and $\theta_{\text {eq }}=\theta \cong \theta_{\mathrm{f}}$. Finally, the $\mathrm{AB}$ of a balanced PAYG system with the CA will be:

\begin{tabular}{|c|c|}
\hline ASSETS & LIABILITIES \\
\hline \multirow{2}{*}{$\begin{array}{l}\text { Contribution Asset, } \mathrm{CA}_{\mathrm{t}} \\
\text { (Formula } 18 \text { or 24, (present value) flow of } \\
\text { contributions based on current contributors and } \\
\text { the turnover duration if the conditions prevailing at } \\
\text { the time of valuation remain constant.) }\end{array}$} & $\begin{array}{l}\text { Liability to current pensioners, } V_{t}^{\mathrm{r}} \\
\text { (Formula 11, with } \mathrm{d}=\mathrm{G} \text { ) }\end{array}$ \\
\hline & $\begin{array}{l}\text { Liability to current contributors } V_{t}^{\mathrm{c}} \\
\text { (Formula 12, with } \mathrm{d}=\mathrm{G})\end{array}$ \\
\hline Total Assets & Total Liabilities \\
\hline
\end{tabular}

Whereas with the HA it will be:

\begin{tabular}{|c|c|}
\hline \multicolumn{2}{|c|}{ Table 2: Actuarial Balance Sheet of a Balanced PAYG System with HA. } \\
\hline ASSETS & LIABILITIES \\
\hline Hidden Asset, HA & Liability to current pensioners, $\mathrm{V}_{\mathrm{t}}^{\mathrm{r}}$ \\
(Formula 11, with $\mathrm{d}=\mathrm{r}$ )
\end{tabular}

And in both cases the solvency ratio, $\mathrm{SR}_{\mathrm{t}}=\frac{\text { Assets }}{\text { Liabilities }}$, is equal to one in the case of a balanced pension system, but more items may appear when compiling an actuarial balance for an already-functioning defined-benefit pension system. These could be financial assets or liabilities that may have accumulated, and the system's deficit or surplus

\section{3.-Using the contribution asset and the hidden asset as solvency indicators: some numerical results.}

In this section we show the results obtained for the actuarial balance when different contribution rates are applied, looking especially at the solvency ratio obtained when using the contribution asset and the hidden asset. Basically it is a question of analysing what would happen in a situation of insolvency. What values would the actuarial balance supply? 


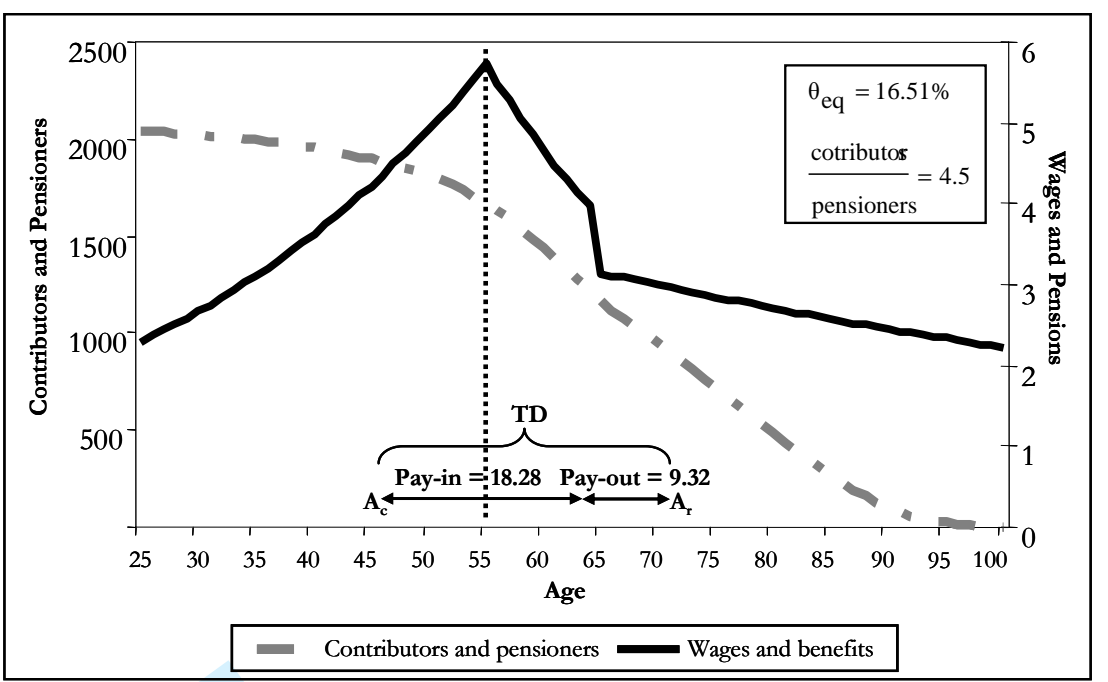

Figure 1: Contributors, pensioners, wages and pensions of the system.

Figure 1 shows contributors and pensioners by age and contribution (wage) and pension structure in a stationary state, 36 years after the inception of the system, assuming that $g$ grows at an annual accumulative rate of $1 \%$ and the population grows at an annual accumulative rate of $2 \%$, and that the pension payable to pensioners at age 65 is $80 \%$ of the previous 40 years' contributions and constant in real terms $(\lambda=0 \%)$. Under these conditions the contribution rate for balance is $16.51 \%$, the TD is 27.59 years (weighted average age of pensioners 73.32 years, weighted average age of contributors 45.72 years), which is distributed over 9.32 years for the pay-out and 18.28 years for the pay-in, and the contributor-pensioner ratio is 4.5 .

\section{BALANCED PENSION SYSTEM}

In this case both the CA and the HA supply a $100 \%$ solvency ratio as the system is balanced in the stationary state. The value of its assets will therefore be the same as the value of its liabilities, although the composition of the liabilities may change. Tables $3 \mathrm{a}, 3 \mathrm{~b}$ and $3 \mathrm{c}$ show the actuarial balance for the CA as well as the HA.

\begin{tabular}{|c|c|c|c|c|c|}
\hline \multicolumn{7}{|c|}{ Table 3a: Balanced Pension System (estimated with CA). } \\
\hline ASSETS & & \multicolumn{4}{c|}{ LIABILITIES } \\
\hline Item & Monetary units & $\%$ & $\%$ & Monetary units & Item \\
\hline Contribution Asset & $1,283,135.10$ & 100 & 33.76 & $433,225.80$ & Liability to Pensioners \\
\hline Accumulated Deficit & 0 & 0 & 66.24 & $849,909.30$ & Liability to Contributors \\
\hline Total Assets & $1,283,135.10$ & $\mathbf{1 0 0}$ & $\mathbf{1 0 0}$ & $1,283,135.10$ & Total Liabilities \\
\hline \multicolumn{7}{|c|}{ G=(1.01)(1.02)-1=0.0302 } \\
\hline
\end{tabular}

\begin{tabular}{|c|c|c|c|c|c|}
\hline \multicolumn{7}{|c|}{ Table 3b: Balanced Pension System (estimated with HA). } \\
\hline ASSETS & LIABILITIES \\
\hline Item & Monetary units & $\%$ & $\%$ & Monetary units & Item \\
\hline Hidden Asset & $938,329.77$ & 100 & 43.47 & $407,885.62$ & Liability to Pensioners \\
\hline Accumulated Deficit & 0 & 0 & 56.53 & $530,444.15$ & Liability to Contributors \\
\hline Total Assets & $938,329.77$ & $\mathbf{1 0 0}$ & $\mathbf{1 0 0}$ & $938,329.77$ & Total Liabilities \\
\hline \multicolumn{7}{|c|}{ G=0.0302; $\mathbf{r}=\mathbf{0 . 0 4}$} \\
\hline
\end{tabular}


Naturally in the case where $r \cong G$, as shown earlier, the actuarial balance in the case of both the contribution asset and the hidden asset will show nearly the same amounts.

\section{UNBALANCED PENSION SYSTEM $^{19}$}

Instead of being balanced, the contribution rate (CR) is considered to be $14.94 \%$ ( $\left.\theta_{\mathrm{dq}}\right)$, which is still greater than the fair contribution rate when $r>G$. The debt would also change because of this since the liability for future contributions would increase as these would be made at a lower rate $(14.94 \%<16.51 \%)$ for benefit entitlement ${ }^{20}$.

In this specific case the actuarial balance with the CA would supply a solvency indicator of $84.18 \%$. The value of the accumulated deficit would therefore be the extra contribution the promoter would have to make in order to fulfil its commitments to all contributors and pensioners. This extra contribution could be offset if there had been an accumulated surplus in previous periods.

\begin{tabular}{|c|c|c|c|c|c|}
\hline \multicolumn{7}{|c|}{ Table 4a: Unbalanced Pension System (estimated with CA). } \\
\hline ASSETS & \multicolumn{3}{c|}{ LIABILITIES } \\
\hline Item & Monetary units & $\%$ & $\%$ & Monetary units & Item \\
\hline Contribution Asset & $1,161,026.73$ & $\mathbf{8 4 . 1 8}$ & 31.41 & $433,225.80$ & Liability to Pensioners \\
\hline Accumulated Deficit & $218,250.33$ & 15.82 & 68.59 & $946,051.27$ & Liability to Contributors \\
\hline Total Assets & $1,379,277.06$ & $\mathbf{1 0 0}$ & $\mathbf{1 0 0}$ & $1,379,277.06$ & Total Liabilities \\
\hline G=0.0302; $\theta=16.51 \% ;$ & $\theta_{\mathrm{dq}}=\mathbf{1 4 . 9 4 \%}$ \\
\hline
\end{tabular}

The actuarial balance compiled using the HA will supply a very different solvency indicator. Before the imbalance the excess contribution was $\theta-\theta_{\mathrm{f}}=\theta^{*}$, where $\theta$ is what contributors really pay in a balanced system and $\theta_{\mathrm{f}}$ is what they should pay (depending on the market interest rate). With a situation of imbalance the excess contribution is $\theta_{\mathrm{dq}}-\theta_{\mathrm{f}}=\theta_{\mathrm{dq}}^{*}$

The difference between the two HAs for both situations, before and after imbalance, is:

$$
\left(\theta^{*}-\theta_{\mathrm{dq}}^{*}\right) \sum_{\mathrm{k}=0}^{\mathrm{A}-1} \mathrm{y}_{\left(\mathrm{x}_{\mathrm{e}}+\mathrm{k}, \mathrm{t}\right)} \cdot \mathrm{N}_{\left(\mathrm{x}_{\mathrm{e}}+\mathrm{k}, \mathrm{t}\right)}\left[\frac{1+\mathrm{r}}{\mathrm{r}-\mathrm{G}}\right]=\mathrm{HA}_{\mathrm{t}}-\mathrm{HA}_{\mathrm{t}}^{*}
$$

\footnotetext{
${ }^{19}$ For simplicity, the numerical results in the tables are shown for the unbalanced contribution rates that follow the formulae $\theta_{\text {eq }}-\left(\theta_{\text {eq }}-\theta_{\mathrm{f}}\right) / 2$ and $\theta_{\text {eq }}+\left(\theta_{\text {eq }}-\theta_{\mathrm{f}}\right) / 2$ respectively, where $\theta_{\mathrm{f}}$, in this case, corresponds to the lower $\mathrm{r}$ considered in each example.

20 A problem appears in the unbalanced system when it comes to valuing the liability with contributors because it will not coincide using the prospective or retrospective methods. The liability to contributors will be greater (real) if it is valued with the prospective method rather than the retrospective. The system is unbalanced in favour of the contributors and this is reflected in the calculation.
} 
where $\mathrm{HA}_{\mathrm{t}}$ is the $\mathrm{HA}$ in a balanced situation (equal to the liability) and $\mathrm{HA}_{\mathrm{t}}^{*}$ is the $\mathrm{HA}$ in an unbalanced situation. If we calculate:

$$
\mathrm{HA}_{\mathrm{t}}-\left(\theta^{*}-\theta_{\mathrm{dq}}^{*}\right) \sum_{\mathrm{k}=0}^{\mathrm{A}-1} \mathrm{y}_{\left(\mathrm{x}_{\mathrm{e}}+\mathrm{k}, \mathrm{t}\right)} \cdot \mathrm{N}_{\left(\mathrm{x}_{\mathrm{e}}+\mathrm{k}, \mathrm{t}\right)}\left[\frac{1+\mathrm{r}}{\mathrm{r}-\mathrm{G}}\right]=\mathrm{HA}_{\mathrm{t}}^{*}
$$

or as:

$$
\sum_{k=0}^{A-1} y_{\left(x_{e}+k, t\right)} \cdot N_{\left(x_{e}+k, t\right)}\left[\frac{1+r}{r-G}\right]=\frac{H A_{t}}{\theta^{*}}
$$

substituting in the previous formula:

$$
\operatorname{HA}_{\mathrm{t}}\left(\frac{\theta_{\mathrm{dq}}^{*}}{\theta^{*}}\right)=\operatorname{HA}_{\mathrm{t}}^{*}=\operatorname{HA}_{\mathrm{t}}\left(\frac{\theta_{\mathrm{dq}}-\theta_{\mathrm{f}}}{\theta-\theta_{\mathrm{f}}}\right)
$$

\begin{tabular}{|c|c|c|c|c|c|}
\hline \multicolumn{6}{|c|}{ Table 4c: Unbalanced Pension System (estimated with HA). } \\
\hline \multicolumn{3}{|c|}{ ASSETS } & \multicolumn{3}{|c|}{ LIABILITIES } \\
\hline Item & Monetary units & $\%$ & $\%$ & Monetary units & Item \\
\hline Hidden Asset & $458,552.23$ & 59.59 & 50.01 & $384,839.69$ & Liability to Pensioners \\
\hline Accumulated Deficit & $310,915.69$ & 40.41 & 49.99 & $384,628.23$ & Liability to Contributors \\
\hline Total Assets & $769,467.92$ & 100 & 100 & $769,467.92$ & Total Liabilities \\
\hline
\end{tabular}

the results for assets, liabilities and the solvency ratio are:

\begin{tabular}{|c|c|c|c|c|c|}
\hline \multicolumn{7}{|c|}{ Table 4b: Unbalanced Pension System (estimated with HA). } \\
\hline ASSETS & \multicolumn{4}{c|}{ LIABILITIES } \\
\hline Item & Monetary units & $\%$ & $\%$ & Monetary units & Item \\
\hline $\begin{array}{c}\text { Hidden Asset } \\
\text { (Equation 29) }\end{array}$ & $468,677.44$ & $\mathbf{4 5 . 7 8}$ & 39.85 & $407,885.62$ & Liability to Pensioners \\
\hline Accumulated Deficit & $554,996.81$ & 54.22 & 60.15 & $615,788.63$ & Liability to Contributors \\
\hline Total Assets & $1,023,674.25$ & $\mathbf{1 0 0}$ & $\mathbf{1 0 0}$ & $1,023,674.25$ & Total Liabilities \\
\hline \multicolumn{3}{|c|}{ G=0.0302; r $=\mathbf{0 . 0 4} ; \boldsymbol{\theta}=\mathbf{1 6 . 5 1 \% ;} \theta_{\mathrm{dq}}=\mathbf{1 4 . 9 4 \% ; \quad \mathrm { f }}=\mathbf{1 3 . 3 7 \%}$} \\
\hline
\end{tabular}

It can be seen how the solvency ratio in the case of the HA is highly volatile when there is a change in the market interest rate (which has no effect on the PAYG pension system $)^{21}$. The results that appear are clearly inconsistent from the point of view of the system's solvency. For a contribution rate of 14.94 (18.08) \% and a market interest rate of $4 \%$, the solvency ratio (SR) would barely reach 45.78 (164.95) \% as opposed to 84.18 (118.35) \% if the CA were used. The fact that the system's solvency ratio is affected by an assumption on a variable that has no impact on either the flow of contributions or the flow of benefits is, if not proof, a strong indicator of the theoretical weakness of the "hidden asset" as a measure of solvency in a PAYG pension system.

\footnotetext{
${ }^{21}$ Using historical data from 1981 to 2006, D’Abbio et al. (2009) attempt to measure the degree of uncertainty in investment returns. The results show a median real return of $7.3 \%$ a year on a portfolio equally weighted between equities and bonds (averaged across the countries studied). The degree of uncertainty, even with the relatively long investment horizons of pensions, is found to be large. In $10 \%$ of cases, an annual return of less than $5.5 \%$ would be expected, while in $10 \%$ of cases this would exceed $9.0 \%$.
} 


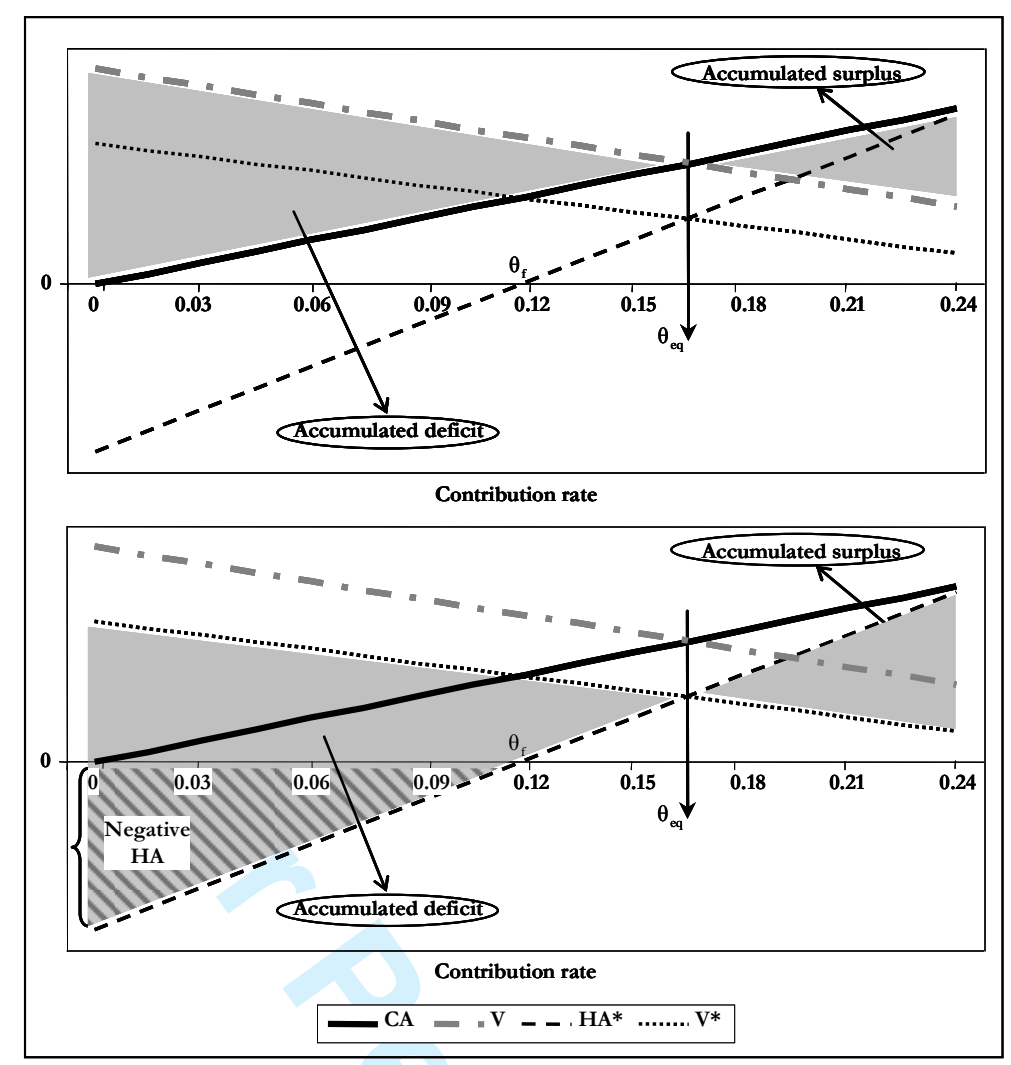

Figure 2: $\mathrm{CA}$ versus HA, $\mathrm{r}=0.05, \mathrm{~g}=0.01, \gamma=0.02$

The results for the accumulated deficit or surplus for various contribution rates and a market interest rate of $5 \%$ are shown in Figure 2. It can be seen that for $\theta_{\text {eq }}=16.51 \%$, the assets and liabilities coincide and the accumulated deficit is zero. For lower (higher) contribution rates the assets are lower (higher) than the liabilities, therefore the accumulated deficit (surplus) is positive and the solvency ratio worsens (improves).

Figure 3 shows solvency levels using the CA and the HA for different contribution rates and market interest rates.

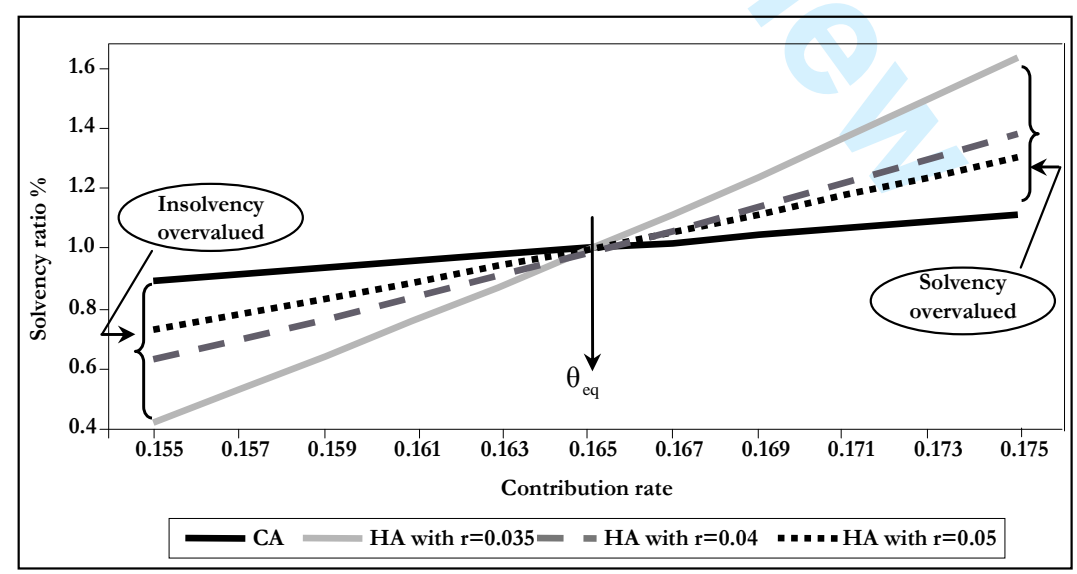

Figure 3: Solvency ratio using CA and HA

It can be seen how the situation of solvency is overvalued compared to that calculated under the contribution asset in those cases where contribution rates are above the balanced rates, and this overvaluation is greater the smaller the difference between $G$ and $\mathrm{r}$. Similarly there appears an overvaluation of the situation of insolvency in those cases 
where the contribution rates are lower than those for a balanced state, and this overvaluation is greater the smaller the difference between $G$ and $r$.

The results (consistency and inconsistency) are robust to changes in population growth rate, mortality tables, the age-wage structure, the growth rate of pensions in payment, etc. See Appendix 2.

\section{4.-Concluding comments}

When compiling the official actuarial balance for the PAYG system, public social security administrations basically use two approaches: the so-called "Swedish" and "US" models. The "Swedish" model is a very recent one as it has only been carried out officially since 2001 and is innovative in that it adopts the typical structure of accounting balance sheets by having a list of assets and liabilities. The main methodological innovation enabling the actuarial balance to be compiled is what is known as the contribution asset, although its theoretical basis needs to be further analysed in the literature. Only the papers by Settergren \& Mikula (2005) and Boado-Penas et al (2008) have looked at it in any detail. At the same time some authors have questioned the validity of the concept, Andrews (2008), or have expressed doubts about it, Robalino \& Bodor (2009), suggesting that the contribution asset should be replaced by the "PAYG asset", which is another name for what other authors mentioned in this paper call the "hidden asset", the "hidden tax" or the "implicit tax on pensions".

In order to shed some light on the basic theory behind the contribution asset and its connection with the possible alternative known as the hidden asset, this paper has developed an overlapping generations model and applied it to the defined-benefit PAYG system, though it would be equally valid for NDC systems. We deduced both assets from this model and derived the basic properties of the turnover duration, which is a necessary element for enabling the contribution asset to be calculated. The main theoretical finding is that, despite their very different natures, the HA and the CA may nearly coincide at the limit where the interest rate of the financial market approaches the growth of the covered wage bill from above.

In the applied section, in order to compile the actuarial balance as a solvency indicator for the "Swedish" model, there are three main reasons as to why it is better to use the contribution asset:

(1) its financial-actuarial basis in the PAYG system, which makes it unnecessary to use the interest rate of the financial market to answer the questions: 'What is the value of the commitment to contributors and pensioners taken on by the system?' and 'What are the assets that back up this commitment?';

(2) it is easy to calculate as there is no need to make projections; and

(3) it is clear in diagnosing insolvency because, as shown in the previous section, the use of the hidden asset supplies a solvency indicator which is not always consistent with the financial health of the system - the solvency indicator supplied by the HA is highly volatile when there is a change in the market interest rate (which has no effect on the PAYG pension system).

The fact that the solvency ratio of the system is affected by an assumption on a variable that has no impact on either the flow of contributions or the flow of benefits is, if not proof, a strong indicator of the theoretical weakness of the "hidden asset" as a measure of solvency in a PAYG pension system. However, there is an important limitation when using the CA to compile the actuarial balance insofar as, in order to calculate the TD, the 
only contingency taken into account is retirement. Other contingencies such as disability or survivor benefits make it more difficult to define the TD in both theoretical and practical terms.

\section{5.-References.}

Andrews, D. (2008): "A Review and Analysis of the Sustainability and Equity of Social Security Adjustment Mechanisms". Thesis presented to the University of Waterloo, Canada.

Auerbach, A. J. and R. D. Lee (2009a): "Welfare and Generational Equity in Sustainable Unfunded Pension Systems" National Bureau of Economic Research, WP-14682.

Auerbach, A. J. and R. D. Lee (2009b): "Notional Defined Contribution Pension Systems in a Stochastic Context: Design and Stability," Chapter 2 in J. Brown, J. Liebman, and D. Wise, eds., Social Security Policy in a Changing Environment. University of Chicago Press: Chicago.

Boado-Penas, C. and C. Vidal-Meliá (2011): "The Actuarial Balance of the Pay-As-You-Go Pension System: the Swedish NDC model versus the US DB model." In "Non-Financial Defined Contribution (NDC) Pension Systems: Progress and New Frontiers in a Changing Pension World". Edited by Robert Holzmann, Edward Palmer and David Robalino. The World Bank and Riksforsakrings Verket. Forthcoming.

Boado-Penas, C, S. Valdés-Prieto and C. Vidal-Meliá (2008): “An Actuarial Balance Sheet for Pay-As-You-Go Finance: Solvency Indicators for Spain and Sweden”. Fiscal Studies, 29, 89-134.

Board of Trustees, Federal Old-Age and Survivors Insurance and Disability Insurance Trust Funds (BOT) (2010). 2009 Annual Report. Washington, D.C.: Government Printing Office.

Cigno, A. (2008): “Is there a Social Security Tax Wedge?” Labour Economics, 15(1), 68-77.

D'Addio, A. C., J. Seisdedos and E. R. Whitehouse (2009): “Investment Risk and Pensions: Measuring Uncertainty in Returns", OECD Social, Employment and Migration WP-70, OECD Publishing.

Demange, G. (2002): “On optimality of intergenerational risk sharing”, Economic Theory 20, pp.1-27.

Disney, R.F. (2004): "Are contributions to public pension programmes a tax on employment?". Economic Policy, 19, 267-311.

Fenge, R. and M. Werding (2004): "Ageing and the tax implied in public pension schemes: simulations for selected OECD countries". Fiscal Studies, 25, 159-200.

Fenge, R. and M. Werding (2003): "Ageing and fiscal imbalances across generations: concepts of measurement". Cesifo, WP-842.

Jackson, H. E. (2004): “Accounting for Social Security and Its Reform” 41 Harvard Journal of Legislation 59, winter.

Geanokoplos, J., O. Mitchell and S. Zeldes (1998): "Would Privatized Social Security Systems really have a higher rate of return?", in Framing the Social Security Debate: Values, Politics, and Economics, R. Douglas Arnold, Michael J. Graetz, and Alicia H. Munnell, eds., National Academy of Social Insurance, Brookings Institution Press.

Gronchi, S. and S. Nisticò (2008): "Theoretical Foundations of Pay-as-You-Go DefinedContribution Pension Schemes". Metroeconomica, 59, 131-159. 
Knell, M. (2005a): "On the Design of Sustainable and Fair PAYG Pension Systems When Cohort Sizes Change". Oesterreichische Nationalbank, WP-95.

Knell, M. (2005b): Demographic Adjustment Factors for Sustainable PAYG Pension Systems. Oesterreichische Nationalbank, Economic Studies Division. Mimeo.

Krueger, D. and F. Kubler (2006): "Pareto Improving Social Security Reform when Financial Markets are Incomplete" American Economic Review 96 (3), 737-755.

Lindbeck, A. and M. Persson (2003): “The Gains from Pension Reform” Journal of Economic Literature, Vol. XLI (March), 74-112.

Lüdecke, R. (1988): "Staatsverschuldung, intergenerative redistribution und umlagefinanzierte gesetzliche Rentenversicherung: Eine andere Sicht der lasten durch ein negatives Bevölkerungswachstum", in J. Kalus and P. Klemmer (eds.) Wirtschaftliche Strukturproblemeund Soziale Fragen: Analysen und Gestaltungsaufgaben, Berlin: Duncker \& Humblot.

Robalino, D. and A. Bodor. (2009): "On the Financial Sustainability of Earnings Related Pay-as-you-go Systems and the Role of Government Indexed Bonds". Journal of Pension Economics and Finance. 8 (2): 153-187.

Settergren, O (2003): "Financial and Inter-Generational Balance? An Introduction to How the Swedish Pension System Manages Conflicting Ambitions." Scandinavian Insurance Quarterly 2, 99-114.

Settergren, O (2001): "The Automatic Balance Mechanism of the Swedish Pension System a non-technical introduction”. Wirtschaftspolitische Blätter 4/2001, 339-349.

Settergren, O. and B.D. Mikula (2005): "The rate of return of pay-as-you-go pension systems: a more exact consumption-loan model of interest" The Journal of Pensions Economics and Finance, 4 (2), 115-138

Sinn, H.W. (2000): "Why a funded pension is useful and why it is not", International Tax and Public Finance 7, 389-410.

The Swedish Pension System. Orange Annual Report 2009. (2010). Ed. Gudrun Ehnsson, Swedish Pensions Agency (Försäkringskassan), Stockholm.

Tirole, J. (1985): “Asset Bubbles and Overlapping Generations”, Econometrica, 53, 1499-1528

Thogersen, O. (2001): "Reforming social security: assessing the effect of alternative funding strategies", Applied economics, 33 (12), 1531-1540.

Valdés-Prieto, S. (2005): "Securitization of taxes implicit in PAYG pensions". Economic Policy 20 (4), 215-265

Valdés-Prieto, S. (2002). Políticas y mercados de pensiones. Ediciones Universidad Católica de Chile, Santiago de Chile.

Vidal-Meliá, C. and M.C. Boado-Penas (2010): "Notes on Using the Hidden Asset or Contribution Asset to Compile the Actuarial Balance for Pay-As-You-Go Pension Systems" FUNCAS, WP-571/2010.

Vidal-Meliá, C., M.C. Boado-Penas and O. Settergren (2010): "Instruments for improving the equity, transparency and solvency of pay-as-you-go pension systems: NDCs, ABs and ABMs." Chapter 18 in M. Micocci, G. N. Gregoriou and G. B. Masala, eds., Pension Fund Risk. Management. Financial and Actuarial Modelling. Chapman \& Hall/CRC Finance Series. 


\section{Appendix 1.-Some numerical examples of the properties of the TD developed in} Section 2.1

Basic scenario or state: It is assumed that g grows at an annual accumulative rate of $1 \%$ and the population $(\gamma)$ at an annual accumulative rate of $2 \%$, and that the pension payable to pensioners at age 65 is $80 \%$ of the previous 40 years' contributions and constant in real terms $(\lambda=0 \%)$.

Under these conditions the contribution rate for balance is $16.51 \%$, the TD is 27.59 years (weighted average age of pensioners 73.32 years, weighted average age of contributors 45.72 years), which is distributed over 9.32 years for the pay-out and 18.28 years for the pay-in, and the contributor-pensioner ratio is 4.5 .

1. For $\gamma=2 \%$, and $g=\lambda=2 \%$; and $g=\lambda=1 \%$; and $g=\lambda=-2 \%$

\begin{tabular}{|c|c|l|l|l|l|l|c|}
\hline \multicolumn{7}{|c|}{ Table 5a. } \\
\hline Assumptions & TD & $\mathbf{A}_{\mathbf{r}}$ & $\mathbf{A}_{\mathbf{c}}$ & $\mathbf{p t}_{\mathbf{r}}$ & $\mathbf{p t}_{\mathbf{c}}$ & $\mathbf{C R}$ & $\frac{\text { contributor }}{\text { pensioner }}$ \\
\hline$\gamma=2 \%$ and $\mathrm{g}=\lambda=2 \%$ & $\mathbf{2 8 . 0 4}$ & $\mathbf{7 3 . 7 6}$ & $\mathbf{4 5 . 7 2}$ & $\mathbf{9 . 7 6}$ & $\mathbf{1 8 . 2 8}$ & $\mathbf{1 7 . 8 0} \%$ & 4.50 \\
\hline$\gamma=2 \%$ and $\mathrm{g}=\lambda=1 \%$ & $\mathbf{2 8 . 0 4}$ & $\mathbf{7 3 . 7 6}$ & $\mathbf{4 5 . 7 2}$ & $\mathbf{9 . 7 6}$ & $\mathbf{1 8 . 2 8}$ & $\mathbf{1 7 . 9 8 \%}$ & 4.50 \\
\hline$\gamma=2 \%$ and $\mathrm{g}=\lambda=-2 \%$ & $\mathbf{2 8 . 0 4}$ & $\mathbf{7 3 . 7 6}$ & $\mathbf{4 5 . 7 2}$ & $\mathbf{9 . 7 6}$ & $\mathbf{1 8 . 2 8}$ & $\mathbf{1 8 . 5 3 \%}$ & 4.50 \\
\hline
\end{tabular}

2. $\gamma=2 \%$, and $g=1 \%-\lambda=0 \%$; and $g=3 \%-\lambda=2 \%$;

\begin{tabular}{|c|c|l|c|c|c|c|c|}
\hline \multicolumn{7}{|c|}{ Table 5b. } \\
\hline Assumptions & $\mathbf{T D}$ & $\mathbf{A}_{\mathbf{r}}$ & $\mathbf{A}_{\mathbf{c}}$ & $\mathbf{p t}_{\mathbf{r}}$ & $\mathbf{p t}_{\mathbf{c}}$ & $\mathbf{C R}$ & $\frac{\text { contributor }}{\text { pensioner }}$ \\
\hline$\gamma=2 \%, \lambda=0 \%, \mathrm{~g}-\lambda=1 \%$ & $\mathbf{2 7 . 5 9}$ & $\mathbf{7 3 . 3 2}$ & $\mathbf{4 5 . 7 2}$ & $\mathbf{9 . 3 2}$ & $\mathbf{1 8 . 2 8}$ & $\mathbf{1 6 . 5 1 \%}$ & 4.50 \\
\hline$\gamma=2 \%, \lambda=0 \%, \mathrm{~g}-\lambda=3 \%$ & $\mathbf{2 6 . 7 8}$ & $\mathbf{7 2 . 5 0}$ & $\mathbf{4 5 . 7 2}$ & $\mathbf{8 . 5 0}$ & $\mathbf{1 8 . 2 8}$ & $\mathbf{1 3 . 8 7 \%}$ & 4.50 \\
\hline
\end{tabular}

3. Basic scenario and $\gamma=3 \%$ and $\gamma=1 \%$

\begin{tabular}{|c|c|l|l|l|l|l|c|}
\hline \multicolumn{7}{|c|}{ Table 5c. } \\
\hline Assumptions & TD & $\mathbf{A}_{\mathbf{r}}$ & $\mathbf{A}_{\mathbf{c}}$ & $\mathbf{p t}_{\mathbf{r}}$ & $\mathbf{p t}_{\mathbf{c}}$ & $\mathbf{C R}$ & $\frac{\text { contributor }}{\text { pensioner }}$ \\
\hline$\lambda=0 \%, \mathrm{~g}=1 \%, \gamma=2 \%$ & $\mathbf{2 7 . 5 9}$ & $\mathbf{7 3 . 3 2}$ & $\mathbf{4 5 . 7 2}$ & $\mathbf{9 . 3 2}$ & $\mathbf{1 8 . 2 8}$ & $\mathbf{1 6 . 5 1 \%}$ & 4.50 \\
\hline$\lambda=0 \%, \mathrm{~g}=1 \%, \gamma=3 \%$ & 27.17 & $\mathbf{7 2 . 9 0}$ & $\mathbf{4 5 . 7 2}$ & $\mathbf{8 . 9 0}$ & $\mathbf{1 8 . 2 8}$ & $\mathbf{1 5 . 1 1 \%}$ & 4.94 \\
\hline$\lambda=0 \%, \mathrm{~g}=1 \%, \gamma=1 \%$ & $\mathbf{2 8 . 0 4}$ & $\mathbf{7 3 . 7 6}$ & 45.72 & $\mathbf{9 . 7 6}$ & $\mathbf{1 8 . 2 8}$ & $\mathbf{1 8 . 1 4 \%}$ & 4.08 \\
\hline
\end{tabular}


4. Basic scenario different combinations of $(1+G)=1.0302$.

\begin{tabular}{|c|c|c|c|c|c|c|c|}
\hline \multicolumn{7}{|c|}{ Table 5d. } & \\
\hline Assumptions & TD & $\mathbf{A}_{\mathbf{r}}$ & $\mathbf{A}_{\mathbf{c}}$ & $\mathbf{p t}_{\mathbf{r}}$ & $\mathbf{p t}_{\mathbf{c}}$ & $\mathbf{C R}$ & $\frac{\text { contributor }}{\text { pensioner }}$ \\
\hline $\begin{array}{c}\lambda=0 \%, \mathrm{~g}=1 \%, \gamma=2 \%, \\
(1+\mathrm{G})=1.0302\end{array}$ & 27.59 & 73.32 & 45.72 & $\mathbf{9 . 3 2}$ & 18.28 & $16.51 \%$ & 4.50 \\
\hline $\begin{array}{c}\lambda=0 \%, \mathrm{~g}=2 \%, \gamma=1 \%, \\
(1+\mathrm{G})=1.0302\end{array}$ & 27.59 & 73.32 & 45.72 & $\mathbf{9 . 3 2}$ & 18.28 & $16.51 \%$ & 4.08 \\
\hline $\begin{array}{c}\lambda=0 \%, \mathrm{~g}=3.02 \%, \gamma=0 \%, \\
(1+\mathrm{G})=1.0302\end{array}$ & 27.59 & 73.32 & 45.72 & $\mathbf{9 . 3 2}$ & 18.28 & $16.51 \%$ & 3.67 \\
\hline $\begin{array}{c}\lambda=0 \%, \mathrm{~g}=0 \%, \gamma=3.02 \%, \\
(1+\mathrm{G})=1.0302\end{array}$ & 27.59 & 73.32 & 45.72 & $\mathbf{9 . 3 2}$ & 18.28 & $16.51 \%$ & 4.94 \\
\hline
\end{tabular}

5. Basic scenario and different salary profile.

\begin{tabular}{|c|c|c|c|c|c|c|c|}
\hline \multicolumn{3}{|c|}{$V \quad V$} & \multicolumn{5}{|c|}{ Table 5e. } \\
\hline Assumptions & TD & $\mathbf{A}_{\mathrm{r}}$ & $\mathbf{A}_{\mathrm{c}}$ & $\mathrm{pt}_{\mathrm{r}}$ & $\mathrm{pt}_{\mathrm{c}}$ & CR & $\frac{\text { contributor }}{\text { pensioner }}$ \\
\hline Basic & 27.59 & 73.32 & 45.72 & 9.32 & 18.28 & $16.51 \%$ & 4.50 \\
\hline Perfil 1 (decreasing) & 32.67 & 73.32 & 40.65 & 9.32 & 23.35 & $15.79 \%$ & 4.94 \\
\hline Perfil 4 (increasing) & 27.64 & 73.32 & 45.68 & 9.32 & 18.32 & $16.68 \%$ & 4.94 \\
\hline
\end{tabular}

6A. Basic scenario and 1.5\% more probability of surviving from 65 onwards; $1.5 \%$ less probability of surviving from 65 onwards.

\begin{tabular}{|c|c|l|l|l|l|l|c|}
\hline \multicolumn{7}{|c|}{ Table 5f. } \\
\hline Assumptions & TD & $\mathbf{A}_{\mathbf{r}}$ & $\mathbf{A}_{\mathbf{c}}$ & $\mathrm{pt}_{\mathbf{r}}$ & $\mathbf{p t}_{\mathbf{c}}$ & $\mathbf{C R}$ & $\frac{\text { contributor }}{\text { pensioner }}$ \\
\hline No changes after 65 & $\mathbf{2 7 . 5 9}$ & $\mathbf{7 3 . 3 2}$ & $\mathbf{4 5 . 7 2}$ & $\mathbf{9 . 3 2}$ & $\mathbf{1 8 . 2 8}$ & $\mathbf{1 6 . 5 1 \%}$ & 4.50 \\
\hline Decreasing after 65 & $\mathbf{2 6 . 9 2}$ & $\mathbf{7 2 . 6 4}$ & $\mathbf{4 5 . 7 2}$ & $\mathbf{8 . 6 4}$ & $\mathbf{1 8 . 2 8}$ & $\mathbf{1 4 . 5 7 \%}$ & $\mathbf{5 . 1 3}$ \\
\hline Increasing after 65 & $\mathbf{2 8 . 0 7}$ & $\mathbf{7 4 . 0 5}$ & $\mathbf{4 5 . 7 2}$ & $\mathbf{1 0 . 0 5}$ & $\mathbf{1 8 . 2 8}$ & $\mathbf{1 8 . 8 9 \%}$ & $\mathbf{3 . 9 0}$ \\
\hline
\end{tabular}

6b. Basic scenario and 3\% more probability of surviving from 70 onwards; $3 \%$ less probability of surviving from 70 onwards.

\begin{tabular}{|c|c|c|c|c|c|c|c|}
\hline \multicolumn{8}{|c|}{ Table 5g. } \\
\hline Assumptions & TD & $\mathbf{A}_{\mathrm{r}}$ & $\mathbf{A}_{\mathbf{c}}$ & $\mathrm{pt}_{\mathrm{r}}$ & $\mathrm{pt}_{\mathrm{c}}$ & CR & $\frac{\text { contributor }}{\text { pensioner }}$ \\
\hline No changes after 70 & 27.59 & 73.32 & 45.72 & 9.32 & 18.28 & $16.51 \%$ & 4.50 \\
\hline Decreasing after 70 & 26.61 & 72.33 & 45.72 & 8.33 & 18.28 & $14.78 \%$ & 5.08 \\
\hline Increasing after 70 & 28.80 & 74.52 & 45.72 & 10.52 & 18.28 & $18.92 \%$ & 3.88 \\
\hline
\end{tabular}

7. Variations of retirement age: $x_{e}+A=60$ and $x_{e}+A=70$

\begin{tabular}{|c|c|c|c|c|c|c|c|}
\hline \multicolumn{7}{|c|}{ Table 5h. } \\
\hline Assumptions & TD & $\mathbf{A}_{\mathbf{r}}$ & $\mathbf{A}_{\mathbf{c}}$ & $\mathbf{p t}_{\mathbf{r}}$ & $\mathbf{p t}_{\mathbf{c}}$ & $\mathbf{C R}$ & $\frac{\text { contributor }}{\text { pensioner }}$ \\
\hline No changes & $\mathbf{2 7 . 5 9}$ & $\mathbf{7 3 . 3 2}$ & 45.72 & $\mathbf{9 . 3 2}$ & $\mathbf{1 8 . 2 8}$ & $\mathbf{1 6 . 5 1 \%}$ & 4.50 \\
\hline $\mathrm{x}_{\mathrm{e}}+\mathrm{A}=60$ & $\mathbf{2 5 . 6 9}$ & $\mathbf{6 9 . 5 9}$ & 43.89 & 10.59 & $\mathbf{1 5 . 1 1}$ & $\mathbf{2 3 . 2 1 \%}$ & 3.15 \\
\hline $\mathrm{x}_{\mathrm{e}}+\mathrm{A}=70$ & 29.75 & $\mathbf{7 6 . 8 8}$ & 47.13 & 7.88 & $\mathbf{2 1 . 8 7}$ & $\mathbf{1 1 . 3 5 \%}$ & $\mathbf{6 . 6 0}$ \\
\hline
\end{tabular}


8. Variations in the number of generations of contributors for a particular retirement age: $x_{e}$ $=20$ and $: x_{e}=30$

\begin{tabular}{|c|c|c|c|c|c|c|c|}
\hline \multicolumn{7}{|c|}{ Table 5i. } \\
\hline Assumptions & TD & $\mathbf{A}_{\mathbf{r}}$ & $\mathbf{A}_{\mathbf{c}}$ & $\mathrm{pt}_{\mathbf{r}}$ & $\mathbf{p t}_{\mathbf{c}}$ & $\mathbf{C R}$ & $\frac{\text { contributor }}{\text { pensioner }}$ \\
\hline No changes & 27.59 & 73.32 & 45.72 & $\mathbf{9 . 3 2}$ & 18.28 & $16.51 \%$ & 4.50 \\
\hline $\mathrm{x}_{\mathrm{e}}=20$ & 29.27 & 73.32 & 44.05 & $\mathbf{9 . 3 2}$ & 19.95 & $14.54 \%$ & $\mathbf{5 . 1 3}$ \\
\hline $\mathrm{x}_{\mathrm{e}}=30$ & 25.79 & 73.32 & 47.53 & $\mathbf{9 . 3 2}$ & 16.47 & $19.10 \%$ & 3.87 \\
\hline
\end{tabular}

9. Variations $\mathrm{s}^{22}$ in the number of generations of pensioners for a particular retirement age, $\mathrm{w}=91$ and $\mathrm{w}=111$.

\begin{tabular}{|c|c|l|l|l|l|l|c|}
\hline \multicolumn{9}{|c|}{ Table 5j. } \\
\hline Assumptions & TD & $\mathbf{A}_{\mathbf{r}}$ & $\mathbf{A}_{\mathbf{c}}$ & $\mathbf{p t}_{\mathbf{r}}$ & $\mathbf{p t}_{\mathbf{c}}$ & $\mathbf{C R}$ & $\frac{\text { contributor }}{\text { pensioner }}$ \\
\hline $\mathrm{w}=91$ & 28.28 & $\mathbf{7 3 . 9 5}$ & 45.67 & $\mathbf{9 . 9 5}$ & $\mathbf{1 8 . 3 3}$ & $\mathbf{1 8 . 0 3 \%}$ & 4.10 \\
\hline $\mathrm{w}=101$ & 29.40 & 75.07 & 45.67 & 11.07 & 18.33 & $\mathbf{1 9 . 0 9 \%}$ & 3.82 \\
\hline $\mathrm{w}=111$ GRdisability & 29.60 & 75.27 & 45.67 & 11.27 & 18.33 & $19.22 \%$ & 3.79 \\
\hline
\end{tabular}

Appendix 2.- Sensitivity analysis of the numerical results shown in Section 3.

Fig. 4 and Tables $6 \mathrm{a}, 6 \mathrm{~b}, 6 \mathrm{c}$ and $6 \mathrm{~d}$ show the main results for the system under different assumptions of population growth, pension growth, different salary profile and a different mortality table respectively.

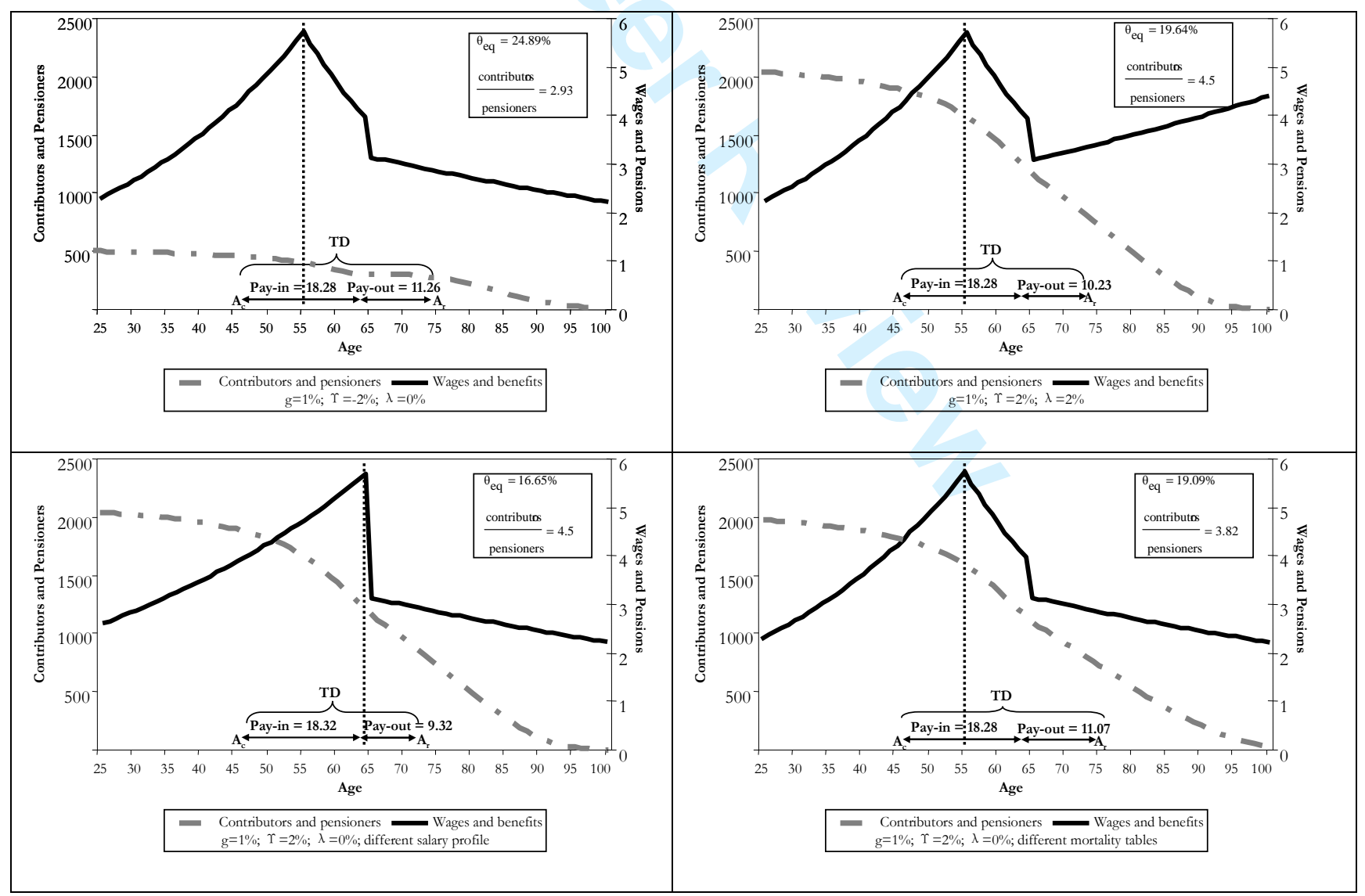

Figure 4: The system's contributors, pensioners, wages and pensions under different assumptions

${ }^{22}$ This sensitivity is carried out using GR-95 tables, which show greater life expectancy. 
${ }^{23}$ For simplicity, the r's are considered to be one and two points above the $G$ for each example. The unbalanced contribution rates shown in the tables follow the formulae described in the text.

${ }^{24}$ In this case, the life expectancy of a person of 65 is 19.63, higher than the result obtained without changing the mortality table (15.61). 